Article

\title{
What Drives Stops in Cross-Border Bond Flows?
}

\author{
Seung-Gwan Baek ${ }^{1}$ and Chi-Young Song ${ }^{2, *(1)}$ \\ 1 School of Economics, Hongik University, 94 Wausan-ro, Mapo-gu, Seoul 04066, Korea \\ 2 Department of Commerce and Finance, Kookmin University, 77 Jeongneung-ro, Seongbuk-gu, \\ Seoul 02707, Korea \\ * Correspondence: cysong@kookmin.ac.kr; Tel.: +82-2-910-4544
}

Received: 9 May 2019; Accepted: 6 July 2019; Published: 10 July 2019

\begin{abstract}
This paper empirically explores the determinants of stop episodes driven by bond flows using quarterly data from 38 economies over the period 1995-2011. Drastic bond-led stop episodes may greatly destabilize domestic financial markets and lead to financial crisis, threatening the sustainability of the financial system. Using the complementary log-log regression method, we found that bond-led stop episodes were associated with contagion and domestic factors rather than global factors. The results of our estimation showed that the probability of bond-led stop episodes was higher in countries with larger financial markets or with more overvalued real exchange rates. The main policy implications of our results, particularly for emerging economies, are that bond-led stop episodes were less likely to occur in countries with higher levels of institutional quality, lower capital account restrictions, or more flexible exchange-rate regimes. Finally, we found that capital control played a relatively greater role in predicting bond-led stops in emerging economies than did exchange-rate regimes.
\end{abstract}

Keywords: Bond; stops; capital controls; exchange-rate regimes; contagion; financial depth

\section{Introduction}

Over the last three decades, the frequent occurrence of extreme cross-border capital flows has been a source of concern for macroeconomic and financial stability in emerging economies (EMEs). The existing literature has examined the causes of extreme capital flow episodes as well as ways of identifying and measuring such episodes. Extreme episodes imply sharp increases (surges) or decreases (stops) in capital flows. Recent studies have identified extreme capital flow episodes and compared heterogeneity across country groups. However, most of them have analyzed extreme events in aggregate capital flows without distinguishing between types of flows. The causes of and policy responses to extreme events may differ depending on the specific components of aggregate capital flows. For example, Pagliari and Hannan [1] and Hannan [2] have shown that the determinants of capital flow volatility differ across financial account instruments.

Few studies have explored the extent and causes of extreme episodes driven by a specific type of capital flow. Using quarterly data over the period 1970-2016, Pagliari and Hannan [1] showed that portfolio debt (bond) is more volatile than foreign direct investment and portfolio equity for gross inflows in EMEs and developing economies and that debt (bond and loan) flows were most volatile before and in the aftermath of the 2008 global financial crisis. Forbes and Warnock [3] also found that the majority of extreme capital flow episodes in their sample were driven by debt flows. Additionally, Baek and Song [4] empirically identified the factors associated with surge and stop episodes in loan flows. As a complementary work aiming to fill the gaps in previous literature, this paper investigates the factors relevant to stop episodes driven by bond flows (hereafter referred to as bond-led stop episodes) and draws policy implications from them. Since the 2000s, the importance of bonds as 
instruments of international funding has been growing fast in EMEs. Using a dataset spanning the period of 2003 Q1-2016 Q1, Cerutti and Hong [5] showed that bond flows had significantly substituted loan flows in EMEs. It is highly possible that bond flows will be a main source of international capital flow, which will cause financial instability in EMEs. Drastic bond-led stops may greatly destabilize domestic financial markets and lead to financial crisis, threatening the sustainability of the financial system. Thus, it is important to analyze the determinants of extreme capital flows with a focus on bond flows in the context of strong financial integration between countries and to figure out policy measures to prevent them.

We define a bond-led "stop" as a sharp cutoff in bond flows initiated by foreign investors (gross capital inflows). Extreme capital flow episodes were originally classified into "sudden stops" and "surges" (Ghosh et al. [6], Montiel and Reinhart [7], Reinhart and Reinhart [8]). A sudden stop (surge) is a sharp decrease (increase) in net capital flows. However, recent studies (Forbes and Warnock [9], Milesi-Ferretti and Tille [10]) have given more weight to gross capital flows than net flows. For example, Forbes and Warnock [9] identified four types of extreme capital flow episodes, namely "surge" and "stop" (sharp increases and decreases, respectively, of gross inflows initiated by foreign investors) and "flight" and "retrenchment" (sharp increases and decreases, respectively, of gross outflows initiated by domestic investors). We followed the latter approach and focused on foreign investors, since extreme episodes, particularly in EMEs, are mostly associated with exceptional behavior of foreign investors rather than domestic investors.

The literature on extreme capital flow episodes or crises has divided their determinants into "push" factors (global or contagion factors) and domestic "pull" factors and has explored whether push or pull factors led to such events (see Hannan [11] and Koepke [12] for a survey of empirical studies on the determinants of capital flows to emerging markets). Some previous studies have found that capital flows or crises in emerging markets are mainly led by global factors: They used various global factors, such as global risk (Gourio et al. [13]), global interest rate (Calvo et al. [14], Chuhan et al. [15], Fernandez-Arias [16], Reyes-Heroles and Tenorio [17], Taylor and Sarno [18]), global liquidity (Brunnermeier [19], Calvo [20], Fratzscher et al. [21]), and global growth rates (Albuquerque et al. [22]). Another push factor is the contagion effect that occurs through trade channels (Abeysinghe and Forbes [23], Forbes [24,25], Glick and Rose [26], Kaminsky et al. [27], Park and Song [28]) or financial channels (Broner et al. [29], Peek and Rosengreen [30]).

Other studies have focused more on the role of domestic pull factors. The first group of domestic variables relevant to cross-border capital flows comprises financial depth, growth shock (Kaminsky et al. [27], Broner et al. [31], Contessi et al. [32]), financial openness (Calvo et al. [33], Kaminsky [34]), and exchange-rate regimes (Ghosh et al. [6]). The second group is related to macroeconomic fundamentals, such as inflation (Claessens and Kose [35], Edwards [36]), current accounts (Agosin and Huaita [37]), real exchange-rate overvaluation (Calvo et al. [33]), and international reserves (Edwards [36]). Country risk (Chuhan et al. [15]) and institutional quality (Ghosh et al. [6], Fratzscher et al. [21], Fratzscher [38]) are also associated with extreme capital flows.

The purpose of this paper is to empirically explore the factors associated with the probability of bond-led stop episodes and compare them to the factors related to extreme episodes driven by aggregate capital flows or the other specific types of capital flows found in previous literature. For estimation, we used a quarterly dataset of 22 advanced economies and 16 EMEs over the period 1995-2011. We closely followed Forbes and Warnock [9] and Baek and Song [4] in identifying extreme capital flow episodes, baseline explanatory variables, and the estimation strategy. The results of our estimation suggest that the determinants of stop episodes vary across types of capital flows and across country groups.

The estimation results indicate that bond-led stop episodes were not significantly correlated with global factors, with the exception of global risk. More important factors were contagion through regional and financial linkages and domestic factors. Forbes and Warnock [3] claimed that stop episodes in debt flows (bond and loan) are primarily associated with global factors rather than domestic pull 
factors. Additionally, Forbes and Warnock [9] found similar results for determinants of stops in aggregate capital flows. In contrast, Baek and Song [4], who examined stop episodes in loan flows driven by foreign investors, found that both global and domestic factors are significantly correlated with the likelihood of such events, particularly in EMEs. However, regarding the contagion effect, all empirical studies, including this paper, have confirmed that financial linkage is the most important channel in extreme capital flow episodes.

We found that, in both EMEs and advanced economies, domestic factors relevant to the likelihood of bond-led stop episodes were financial depth, country indebtedness, and real exchange-rate overvaluation. However, EME episodes were also related to other domestic variables, such as institutional quality, capital controls, and exchange-rate regime. Our results show that bond-led stops were more likely to occur in EMEs with lower institutional quality, greater capital controls, or less flexible exchange-rate regimes. Additionally, unlike previous studies (Forbes and Warnock [3,9], Baek and Song [4]), we found that capital controls and exchange-rate regimes played a significant role in extreme capital flow episodes. The results were verified by various robustness checks. Moreover, we found that capital control played a greater role in predicting bond-led stop episodes in EMEs than did exchange-rate regimes.

The remainder of this paper is organized as follows. Section 2 describes the data and empirical specifications. Section 3 discusses the empirical results, and Section 4 summarizes our main findings and policy implications.

\section{Data and Empirical Specification}

To investigate the factors that significantly affect the probability of bond-led stop episodes, we estimated the following complementary log-log regression model, as in Baek and Song [4]:

$$
\left(\operatorname{Pr}\left(E_{t}^{i}=1\right)=F\left(G_{t-1}^{i} \beta+C_{t-1}^{i} \gamma+D_{t-1}^{i} \delta\right), \text { where } F(z)=1-\exp \{-\exp (z)\},\right.
$$

where $E_{t}^{i}$ is an episode dummy having a value of 1 if country $i$ experiences a stop episode in quarter $t$ and a value of 0 otherwise. $G_{t-1}^{i}, C_{t-1}^{i}$, and $D_{t-1}^{i}$ denote the one-quarter-lagged vectors of global, contagion, and domestic factors, respectively. $F(z)$ indicates a cumulative distribution function. We lagged all explanatory variables by one quarter in order to avoid an endogeneity problem. Compared to logit or probit models, the complementary logarithmic framework is known to be more suitable for the estimation of fairly unbalanced binary-dependent variables, as were present in our sample, since it is built on an asymmetry of the cumulative distribution.

Following the method of Forbes and Warnock [9], we identified stop episodes as follows:

$$
\begin{gathered}
X_{t}=\sum_{i=0}^{3} \text { BINFLOW }_{t-i}, t=1,2,3, \cdots, T \text { and } \\
\Delta X_{t}=X_{t}-X_{t-4}, t=5,6,7, \cdots, T,
\end{gathered}
$$

where $X_{t}$ denotes the four-quarter moving sum of BINFLOW ${ }_{t}$, the quarterly gross inflows of bonds in quarter $t$. We detected stop episodes by comparing $\Delta X_{t}$, the year-to-year change in $X_{t}$, to its threshold value, which equals its five-year rolling mean minus one standard deviation. A stop episode begins when $\Delta X_{t}$ starts to fall below its threshold and ends when it bounces back above the threshold. Additionally, the qualified periods of stop episodes should include at least one quarter in which $\Delta X_{t}$ falls two standard deviations below its rolling mean. Gross bond inflows are measured as portfolio debt liabilities in the International Monetary Fund (IMF)'s "Balance of Payments". In our sample, $\Delta X_{t}$ began in the first quarter of 1995 and ended in the last quarter of 2011.

According to Table 1, during the sample period there were 53 and 41 bond-led stops, respectively, in advanced economies and EMEs, totaling 94 episodes in all countries. The average length of the episodes was 3.9 quarters, and the episodes lasted slightly longer in advanced economies (4.1 quarters) 
than in EMEs (3.7 quarters). We also found regional differences in the average duration of bond-led stops, with such stops lasting longest in North America (5.0 quarters) and shortest in Eastern Europe (3.1 quarters).

Table 1. Summary statistics for stop episodes in bond flows.

\begin{tabular}{lccccc}
\hline Length (in Quarters) & $\mathbf{2 - 3}$ & $\mathbf{4 - 5}$ & $\mathbf{6 - 8}$ & Episodes (Total) & Average Length \\
\hline All Countries & 39 & 42 & 13 & 94 & 3.9 \\
Advanced & 42 & 20 & 10 & 53 & 4.1 \\
Emerging & 13 & 23 & 3 & 41 & 3.7 \\
\hline By Region & & & & & 3.9 \\
Western Europe & 20 & 22 & 6 & 48 & 3.1 \\
Eastern Europe & 6 & 4 & 0 & 10 & 5.0 \\
North America & 2 & 0 & 2 & 4 & 3.7 \\
South America & 5 & 4 & 1 & 10 & 4.3 \\
Asia-Pacific & 5 & 10 & 4 & 19 & 3.7 \\
Others & 1 & 2 & 0 & 3 & \\
\hline
\end{tabular}

Note: (1) Figures in the table indicate the frequency of stops; (2) sample period is 1995 Q1-2011 Q4.

As discussed in Section 1, we used both push factors and domestic pull factors as control variables. Push factors, which are external to a country, comprise global and contagion factors. We used four variables as global factors, namely global risk (VIX), global liquidity, interest rates, and growth. We expected that higher global risk, lower global liquidity, higher global interest rates, and lower global growth would be associated with more stop episodes in gross bond inflows. We used the VIX of the Chicago Board Options Exchange as the variable for global risk. Global liquidity was measured by the sum of monetary supplies in the U.S., Euro area, the U.K., and Japan, and global interest was measured by an average of long-term government bond rates in these countries. Descriptions of data and data sources are presented in Table S1.

We used three contagion variables, namely regional contagion, contagion through trade linkage, and contagion through financial linkage. First, we estimated the contagion effects through geographical linkage using a regional dummy variable. This variable takes a value of 1 if at least one of the countries in the same region experiences an episode and a value of 0 otherwise. Our regional classifications are reported in Table 1.

Second, we measured contagion through trade and financial channels following the methodology of Forbes and Warnock [9]. The measure of contagion through the trade channel in country $i$ at time $t$ $\left(T C_{t}^{i}\right)$ is defined as follows:

$$
T C_{t}^{i}=\frac{\sum_{j}^{n}\left(E X_{j, t}^{i} \times E^{2} \text { dummy }_{j, t}\right)}{\sum_{j}^{n} E X_{j, t}^{i}} \times \frac{E X_{t}^{i}}{G D P_{t}^{i}}, \quad j \neq i,
$$

where $E X_{j, t}^{i}=$ exports from country $i$ to country $j$ in quarter $t, E X_{t}^{i}=$ total worldwide exports from country $i$ in quarter $t$, and $E d u m m y_{j, t}=1$ if an episode is detected in country $j$ in quarter $t$ and 0 otherwise.

The first term in Equation (4) measures how closely the trade of country $i$ is linked to the countries undergoing bond-led stop episodes, and the second term refers to the trade openness of country $i$. $T C_{t}^{i}$ will have a higher value if the trade openness of country $i$ is higher or countries experiencing a bond-led stop episode trade more with country $i$. If no foreign countries experience a stop episode, this variable takes a value of 0 . 
Similarly, we constructed a measure of the contagion of country $i$ through the financial channel $\left(F C_{t}^{i}\right)$, as follows:

$$
F C_{t}^{i}=\frac{\sum_{j}^{n}\left(D E B T_{j, t}^{i} \times E^{\prime} \text { dummy }_{j, t}\right)}{\sum_{j}^{n} D E B T_{j, t}^{i}} \times \frac{D E B T_{t}^{i}}{G D P_{t}^{i}}, j \neq i,
$$

where $D E B T_{j, t}^{i}=$ the amount of investment by country $j$ in the debt securities of country $i$ in quarter $t$, and $D E B T_{t}^{i}=$ the total amount of foreign investment in the debt securities of country $i$ in quarter $t$.

$F C_{t}^{i}$ is also comprised of two terms. The first term measures how closely the debt securities market in country $i$ is linked to the countries experiencing a bond-led stop episode, and the second term measures financial openness with a focus on the debt securities market. The value of $F C_{t}^{i}$ is higher if country $i$ is financially more open or countries experiencing a bond-led stop episode invest more in country $i$ 's debt securities market. We used data on the cross-border holdings of debt securities provided by the IMF's "Coordinated Portfolio Investment Survey (CPIS)" to construct the financial contagion variable.

We used three baseline variables to account for domestic pull factors, namely financial depth, capital controls, and country indebtedness. First, the theoretical relationship between financial depth and the probability of stop episodes is ambiguous. Advanced financial markets are less susceptible to unexpected shocks due to their large numbers of transactions and various types of investors. However, they may also be likely to experience bond-led stops, since higher market liquidity can enable foreign investors to retrieve their money more easily from the domestic financial market. Focusing on stop episodes in bond flows, we measured financial depth using an updated dataset of bond market capitalization (Bond) expressed as a percentage of GDP (Gross Domestic Product) (Beck and Demirgüç-Kunt [39]). For robustness checks, we also used stock market capitalization (M_cap) and domestic credit to the private sector (Pcredit) (expressed as a share of GDP) to measure the depth of financial markets.

Second, capital controls have previously been adopted due to fear of the sudden reversal of capital flows, fear of excessive risk-taking, and to restrain asset price bubbles (Reinhart et al. [40]). However, the results of previous empirical studies on the role of capital controls have been unclear. For example, by studying Chile, Calvo and Talvi [41] pointed out that the imposition of capital controls may increase the size of a sudden stop in net capital flows. A number of studies have also suggested that capital controls increase the risk of currency crises (Kaminsky [34], Bordo et al. [42], Cardarelli et al. [43], Glick and Guo [44]) and exchange-rate volatility (Glick and Hutchison [45]). However, other empirical studies have supported the effectiveness of capital controls in curbing large capital inflows (Ghosh et al. [6], Ostry et al. [46], Stiglitz [47]). For example, Ben Zeev [48] provided empirical evidence that EMEs with strict capital controls can absorb global economic shocks better than those with weak controls. On the other hand, recent studies have found no significant relationship between capital controls and extreme capital flows (Forbes and Warnock [3,9], Baek and Song [4], Fratzscher et al. [21], Forbes et al. [49]). Thus, this relationship remains an unanswered empirical question. As a measure of capital control, we used the overall restrictions index of Fernandez et al. [50], Ka (0-1), in which a higher value means greater capital control.

The third variable was country indebtedness. Countries with larger debt are likely to have a higher probability of bond-led stops, since greater debt can be considered to be a signal of the deterioration of macroeconomic soundness. We measured this variable using the ratio of public debt to GDP, provided by Abbas et al. [51].

The countries in our dataset were chosen based on data availability and are presented in Table S2. We divided the whole sample into two groups, namely EMEs and advanced economies, and examined the similarities and differences between the two groups in the determinants of bond-led stop episodes. Stop episodes were identified based on the full country sample, and this information was used to construct three contagion variables. 


\section{Empirical Results}

\subsection{Baseline Results}

Table 2 presents the results of the estimation using Equation (1) for the sample of EMEs (Columns 1 to 3 ) and advanced economies (Columns 4 to 6 ) and the full sample (Columns 7 to 9), based on the baseline control variables discussed in Section 2. STATA was used for the estimation. We ran pooled regressions for estimation using unbalanced panel data, where the length of the times series was very short in some countries. However, the following points should be considered when interpreting the results from the unbalanced panel data. First, countries with relatively longer time series had larger influences on the estimation results. Thus, the results for the full sample in our empirical analysis may have mainly depended on advanced countries, which had kept longer time series compared to EMEs. Second, although the panel estimation captured both time-dependent and cross-sectional properties, the former properties were relatively weakly reflected in the estimation results compared to the latter properties when unbalanced panel data were used.

We used three different measures of financial market size, and accordingly three results are shown for each data sample. The results for EMEs indicate that bond-led episodes were primarily associated with contagion and domestic factors rather than global factors. However, the role of domestic factors was weak in the sample of advanced economies and the full sample.

These results provide several main empirical findings. First, global risk was positively related to the probability of bond-led stops, confirming the significant role of economic uncertainty and risk aversion in extreme capital flow episodes found in previous studies. Additionally, recent empirical studies have found that global risk is significantly correlated with extreme gross capital flows (Forbes and Warnock [3,9]), surges in net capital flows (Ghosh et al. [6]), stops in cross-border loans (Baek and Song [4]), capital flow volatility (Pagliari and Hannan [1]), and capital flows in the post-global financial crisis era (Hannan [2]). However, there was no significant relationship between the other global factors and bond-led stops. While previous studies have suggested a significant role for global interest rates in stop episodes of debt flows (Forbes and Warnock [3]) and loan flows (Baek and Song [4]), our results indicate that this factor was irrelevant to stops in bond flows. The results of the present study imply that changes in global liquidity, global growth, or interest rates in a large economy such as the United States were not important driving factors for stops in bond flows in both EMEs and advanced economies in our data sample. Second, contagion effects were also important driving factors for stop episodes: However, not all of the three contagion channels were important for stop episodes. Both EMEs and advanced economies were more likely to experience bond-led stops if their neighbors or close financial partners had experienced the same type of episode. Furthermore, previous empirical studies (Baek and Song [4], Forbes and Warnock [3,9]) have found that financial linkage is the most important channel in extreme capital flow episodes. However, bond-led stops were not associated with contagion through trade linkage. The trade channel variables were statistically significantly related to bond-led stops in advanced economies. However, the coefficients were estimated to be negative.

Third, countries with greater financial depth were more vulnerable to bond-led stop episodes. Our results are in line with the findings of Forbes and Warnock [9], suggesting that in countries with greater financial depth, foreign investors have more opportunities not only to invest but also to pull back their claims on domestic assets. A caveat is that only bond market size was relevant to bond-led stops in EMEs, while all three measures of financial depth were relevant in advanced economies, indicating that all types of financial asset markets were well developed in these economies. 
Table 2. The baseline results (pooled regression).

\begin{tabular}{|c|c|c|c|c|c|c|c|c|c|}
\hline & \multicolumn{3}{|c|}{ Emerging Economies } & \multicolumn{3}{|c|}{ Advanced Economies } & \multicolumn{3}{|c|}{ All Economies } \\
\hline & (1) & (2) & (3) & (4) & (5) & (6) & (7) & (8) & (9) \\
\hline \multicolumn{10}{|l|}{ Global Factors } \\
\hline VIX & $\begin{array}{c}0.026^{* *} \\
(2.04)\end{array}$ & $\begin{array}{c}0.023 * \\
(1.68)\end{array}$ & $\begin{array}{c}0.029 * * \\
(2.09)\end{array}$ & $\begin{array}{c}0.038^{* *} \\
(3.15)\end{array}$ & $\begin{array}{c}0.034^{* * *} \\
(2.85)\end{array}$ & $\begin{array}{c}0.039 * * * \\
(3.44)\end{array}$ & $\begin{array}{c}0.034^{* * * *} \\
(3.76)\end{array}$ & $\begin{array}{c}0.032 * * * \\
(3.75)\end{array}$ & $\begin{array}{c}0.037^{* * * *} \\
(4.28)\end{array}$ \\
\hline Liquidity & $\begin{array}{l}0.037 \\
(0.96)\end{array}$ & $\begin{array}{l}0.034 \\
(0.94)\end{array}$ & $\begin{array}{l}0.041 \\
(1.10)\end{array}$ & $\begin{array}{l}0.018 \\
(0.53)\end{array}$ & $\begin{array}{l}0.020 \\
(0.56)\end{array}$ & $\begin{array}{l}0.012 \\
(0.37)\end{array}$ & $\begin{array}{l}0.023 \\
(0.94)\end{array}$ & $\begin{array}{l}0.018 \\
(0.74)\end{array}$ & $\begin{array}{r}0.016 \\
(0.64)\end{array}$ \\
\hline Interest rate & $\begin{array}{l}0.079 \\
(0.26)\end{array}$ & $\begin{array}{l}-0.012 \\
(-0.04)\end{array}$ & $\begin{array}{l}0.162 \\
(0.49)\end{array}$ & $\begin{array}{l}0.202 \\
(0.68)\end{array}$ & $\begin{array}{c}0.25 \\
(0.75)\end{array}$ & $\begin{array}{l}0.059 \\
(0.20)\end{array}$ & $\begin{array}{l}0.196 \\
(0.86)\end{array}$ & $\begin{array}{l}0.098 \\
(0.43)\end{array}$ & $\begin{array}{l}0.078 \\
(0.35)\end{array}$ \\
\hline Growth & $\begin{array}{l}0.034 \\
(0.53)\end{array}$ & $\begin{array}{l}0.031 \\
(0.52)\end{array}$ & $\begin{array}{l}0.053 \\
(0.85)\end{array}$ & $\begin{array}{l}0.069 \\
(0.40)\end{array}$ & $\begin{array}{c}0.12 \\
(1.52)\end{array}$ & $\begin{array}{l}0.113 \\
(1.48)\end{array}$ & $\begin{array}{l}0.038 \\
(0.70)\end{array}$ & $\begin{array}{l}0.082 \\
(1.48)\end{array}$ & $\begin{array}{l}0.077 \\
(1.41)\end{array}$ \\
\hline \multicolumn{10}{|l|}{ Contagion } \\
\hline Regional & $\begin{array}{c}0.754^{* * *} \\
(3.29)\end{array}$ & $\begin{array}{c}0.555^{* *} \\
(2.18)\end{array}$ & $\begin{array}{c}0.589 * * \\
(2.11)\end{array}$ & $\begin{array}{c}0.364^{*} \\
(1.94)\end{array}$ & $\begin{array}{l}0.303 \\
(1.09)\end{array}$ & $\begin{array}{c}0.253 \\
(0.228)\end{array}$ & $\begin{array}{c}0.553^{* * *} \\
(2.94)\end{array}$ & $\begin{array}{c}0.407^{* *} \\
(1.97)\end{array}$ & $\begin{array}{c}0.466^{* *} \\
(2.42)\end{array}$ \\
\hline Trade & $\begin{array}{l}-0.025 \\
(-0.42)\end{array}$ & $\begin{array}{l}-0.065 \\
(-1.18)\end{array}$ & $\begin{array}{l}-0.248 \\
(-0.66)\end{array}$ & $\begin{array}{c}-2.353^{* *} \\
(-2.08)\end{array}$ & $\begin{array}{c}-2.919 * * * \\
(-2.08)\end{array}$ & $\begin{array}{c}-3.654^{* * * *} \\
(-2.83)\end{array}$ & $\begin{array}{l}-0.085 \\
(-1.04)\end{array}$ & $\begin{array}{l}-0.036 \\
(-0.47)\end{array}$ & $\begin{array}{l}-0.933 \\
(-0.92)\end{array}$ \\
\hline Financial & $\begin{array}{c}18.917^{* * *} \\
(6.13)\end{array}$ & $\begin{array}{c}18.930^{* * *} \\
(3.35)\end{array}$ & $\begin{array}{c}18.791 * * * \\
(4.01)\end{array}$ & $\begin{array}{c}1.34^{* * *} \\
(3.16)\end{array}$ & $\begin{array}{c}1.376^{* * *} \\
(2.91)\end{array}$ & $\begin{array}{c}2.028^{* * *} \\
(4.59)\end{array}$ & $\begin{array}{c}1.017 \text { ** } \\
(3.78)\end{array}$ & $\begin{array}{c}0.783^{* * *} \\
(2.55)\end{array}$ & $\begin{array}{c}1.378^{* * *} \\
(3.79)\end{array}$ \\
\hline \multicolumn{10}{|l|}{ Domestic Factors } \\
\hline Bond & $\begin{array}{c}0.003 * * \\
(2.02)\end{array}$ & & & $\begin{array}{c}0.005^{* * *} \\
(3.18)\end{array}$ & & & $\begin{array}{c}0.005^{* * *} \\
(4.19)\end{array}$ & & \\
\hline Pcredit & & $\begin{array}{l}-0.002 \\
(-0.49)\end{array}$ & & & $\begin{array}{c}0.007^{* * *} \\
(2.71)\end{array}$ & & & $\begin{array}{c}0.005^{* * *} \\
(3.35)\end{array}$ & \\
\hline M_cap & & & $\begin{array}{c}.000 \\
(0.07)\end{array}$ & & & $\begin{array}{c}0.005^{* * *} \\
(3.63)\end{array}$ & & & $\begin{array}{c}0.003^{* *} \\
(2.46)\end{array}$ \\
\hline Capital controls & $\begin{array}{c}0.741^{* * *} \\
(3.59)\end{array}$ & $\begin{array}{c}0.801 * * \\
(2.04)\end{array}$ & $\begin{array}{l}0.500 \\
(1.42)\end{array}$ & $\begin{array}{l}0.170 \\
(0.17)\end{array}$ & $\begin{array}{l}0.928 \\
(0.97)\end{array}$ & $\begin{array}{l}0.582 \\
(0.71)\end{array}$ & $\begin{array}{l}0.225 \\
(0.92)\end{array}$ & $\begin{array}{l}0.293 \\
(1.02)\end{array}$ & $\begin{array}{l}-0.042 \\
(-0.15)\end{array}$ \\
\hline Public debt & $\begin{array}{c}-0.024^{* * * *} \\
(-2.79)\end{array}$ & $\begin{array}{c}-0.031^{* * * *} \\
(-2.64)\end{array}$ & $\begin{array}{c}-0.030^{* * * *} \\
(-3.03)\end{array}$ & $\begin{array}{c}-0.008^{* * * *} \\
(-2.05)\end{array}$ & $\begin{array}{l}-0.003 \\
(-0.85)\end{array}$ & $\begin{array}{l}-0.001 \\
(-0.32)\end{array}$ & $\begin{array}{c}-0.007 \text { * } \\
(-1.91)\end{array}$ & $\begin{array}{l}-0.006 \\
(-1.33)\end{array}$ & $\begin{array}{l}-0.005 \\
(-1.06)\end{array}$ \\
\hline Observations & 629 & 651 & 674 & 844 & 851 & 964 & 1473 & 1502 & 1638 \\
\hline
\end{tabular}

Notes: (1) Figures in parentheses are $z$-values; (2) significance at 1\%, 5\%, and 10\% is indicated by *****, and *; (3) sample period is 1995 Q1-2011 Q4. 
Fourth, countries with higher public debt or lower capital controls were less likely to experience bond-led stop episodes. The negative relationship between the probability of bond-led stops and public debt, which is also found in stop episodes of loan flows (Baek and Song [4]), could be attributed to the fact that higher-income economies hold heavy public debt. Meanwhile, the finding that the probability of bond-led stops was positively associated with capital controls was relevant only to EMEs. There was no significant role for capital controls in the sample of advanced economies. Our results contradict previous findings (Ghosh et al. [6], Ostry et al. [46], Stiglitz [47]) in which capital controls were found to be a useful tool in reducing volatility in capital flows. More robustness checks on the role of capital controls will be made in the next subsection.

Overall, global risk and contagion through regional and financial linkages were significantly associated with bond-led stops in both EMEs and advanced economies. Domestic pull factors were more important for EMEs. Bond-led stop episodes were more likely to occur in countries with more developed financial markets. Imposing capital account restrictions did not reduce, but rather increased, the likelihood of stop episodes in EMEs.

Our sample period included both the 1997 East Asian financial crisis and the 2008 global financial crisis. While the latter crisis affected economies around the world, the spread of the former crisis was limited to several East Asian EMEs. Thus, it is possible that the influence of the East Asian crisis caused a bias to our estimation results. In order to determine whether such a problem existed, we re-estimated the baseline equation using a sample period of 2000 Q1-2011 Q4, which did not include the East Asian crisis. We found that the new results were strongly consistent with the original ones presented in Table 2. The significance and signs of the explanatory variables remained intact. We could not find any problems related to the inclusion of the East Asian crisis in our sample. The new results are not reported in order to save space.

Next, we applied country fixed effect regressions to test the robustness of our baseline estimation. The results are shown in Table 3. Since pooled regression did not eliminate the idiosyncratic factors of the sample countries, the estimation results may have strongly reflected the features of particular countries with distinct characteristics in the sample. This problem could be alleviated by using country fixed effect regression. However, the degree of freedom is lower in fixed effect regression than in pooled regression. Table 3 shows that the fixed effect results were mostly consistent with those using pooled regression. Global risk, contagion of regional and financial linkages, capital control, and public debt were found to be significant determinants of bond-led stops, as in the pooled regression. One exception was that statistical significance appeared in the global growth factor for the group of advanced economies.

We extended our baseline model to investigate whether other domestic variables may be significantly associated with stops in bond inflows. We used five country-specific variables relevant to capital flows and crises proposed in the literature, namely domestic growth shock, institutional quality, international reserves, real exchange-rate overvaluation, and exchange-rate regime.

Domestic growth shock (G_shock) represents a pro-cyclical feature of capital inflows (Broner et al. [31], Contessi et al. [32]). Capital inflows increase during the expansionary period of the business cycle and decrease during its contractions. Thus, the probability of stops in bond inflows is likely to be negatively associated with domestic growth shocks. Growth shock is measured by the deviation in the country's actual growth from the trend estimated by the Hodrick-Prescott filter.

We also considered the effect of institutional quality (Quality) on the bond-led stop episodes. Institutional quality refers to the quality level of governance and institutions in a country. This is one of the important factors that determine the efficiency, credibility, resource allocation, and risk of the economy (Bătrâncea et al. [52], Chong and Calderón [53]). Countries with better institutions are expected to be less vulnerable to sudden and sharp outflows of foreign capital (Ghosh et al. [6], Fratzscher et al. [21], Fratzscher [38]). As a measure of institutional quality, we used the political risk index in the "International Country Risk Guide" of the PRS Group. Higher values denote better institutional quality. 
Table 3. The baseline results (fixed effect regression).

\begin{tabular}{|c|c|c|c|c|c|c|c|c|c|}
\hline & \multicolumn{3}{|c|}{ Emerging Economies } & \multicolumn{3}{|c|}{ Advanced Economies } & \multicolumn{3}{|c|}{ All Economies } \\
\hline & (1) & (2) & (3) & (4) & (5) & (6) & (7) & (8) & (9) \\
\hline \multicolumn{10}{|l|}{ Global Factors } \\
\hline VIX & $\begin{array}{c}0.027^{* *} \\
(2.10)\end{array}$ & $\begin{array}{l}0.021 \\
(1.57)\end{array}$ & $\begin{array}{c}0.031^{* *} \\
(2.14)\end{array}$ & $\begin{array}{c}0.035^{* * *} \\
(2.84)\end{array}$ & $\begin{array}{c}0.032 * * * \\
(2.69)\end{array}$ & $\begin{array}{c}0.035^{* * *} \\
(3.00)\end{array}$ & $\begin{array}{c}0.032 * * * \\
(3.52)\end{array}$ & $\begin{array}{c}0.029 * * * \\
(3.31)\end{array}$ & $\begin{array}{c}0.035^{* * *} \\
(4.03)\end{array}$ \\
\hline Liquidity & $\begin{array}{l}0.038 \\
(0.89)\end{array}$ & $\begin{array}{l}0.046 \\
(1.15)\end{array}$ & $\begin{array}{l}0.044 \\
(1.13)\end{array}$ & $\begin{array}{l}0.012 \\
(0.38)\end{array}$ & $\begin{array}{l}0.016 \\
(0.44)\end{array}$ & $\begin{array}{l}0.004 \\
(0.11)\end{array}$ & $\begin{array}{l}0.018 \\
(0.75)\end{array}$ & $\begin{array}{l}0.016 \\
(0.62)\end{array}$ & $\begin{array}{l}0.010 \\
(0.41)\end{array}$ \\
\hline Interest rate & $\begin{array}{l}0.225 \\
(0.72)\end{array}$ & $\begin{array}{l}-0.117 \\
(-0.39)\end{array}$ & $\begin{array}{l}0.201 \\
(0.52)\end{array}$ & $\begin{array}{l}0.121 \\
(0.36)\end{array}$ & $\begin{array}{l}0.339 \\
(0.90)\end{array}$ & $\begin{array}{l}-0.091 \\
(-0.29)\end{array}$ & $\begin{array}{l}0.142 \\
(0.59)\end{array}$ & $\begin{array}{l}0.031 \\
(0.13)\end{array}$ & $\begin{array}{l}-0.038 \\
(-0.16)\end{array}$ \\
\hline Growth & $\begin{array}{l}-0.001 \\
(-0.02)\end{array}$ & $\begin{array}{l}0.022 \\
(0.36)\end{array}$ & $\begin{array}{l}0.015 \\
(0.24)\end{array}$ & $\begin{array}{l}0.092 \\
(1.18)\end{array}$ & $\begin{array}{c}0.137^{*} \\
(1.79)\end{array}$ & $\begin{array}{c}0.145^{*} \\
(1.81)\end{array}$ & $\begin{array}{l}0.039 \\
(0.72)\end{array}$ & $\begin{array}{l}0.082 \\
(1.56)\end{array}$ & $\begin{array}{l}0.077 \\
(1.36)\end{array}$ \\
\hline \multicolumn{10}{|l|}{ Contagion } \\
\hline Regional & $\begin{array}{l}0.704^{* *} \\
(2.36)\end{array}$ & $\begin{array}{c}0.543 * * \\
(1.94)\end{array}$ & $\begin{array}{l}0.562 * \\
(1.67)\end{array}$ & $\begin{array}{l}0.365^{*} \\
(1.77)\end{array}$ & $\begin{array}{l}0.171 \\
(0.57)\end{array}$ & $\begin{array}{l}0.154 \\
(0.60)\end{array}$ & $\begin{array}{c}0.600 * * * \\
(2.95)\end{array}$ & $\begin{array}{l}0.437 * \\
(1.77)\end{array}$ & $\begin{array}{l}0.479 * * \\
(2.19)\end{array}$ \\
\hline Trade & $\begin{array}{l}0.050 \\
(0.66)\end{array}$ & $\begin{array}{l}0.026 \\
(0.49)\end{array}$ & $\begin{array}{l}-0.107 \\
(-0.28)\end{array}$ & $\begin{array}{l}-2.286 \\
(-1.22)\end{array}$ & $\begin{array}{l}-3.497 \\
(-1.51)\end{array}$ & $\begin{array}{l}-3.544 \\
(-1.60)\end{array}$ & $\begin{array}{l}0.002 \\
(0.03)\end{array}$ & $\begin{array}{l}0.161 \\
(1.62)\end{array}$ & $\begin{array}{l}-0.257 \\
(-0.35)\end{array}$ \\
\hline Financial & $\begin{array}{c}14.854^{* * *} \\
(2.82)\end{array}$ & $\begin{array}{c}13.149^{* * *} \\
(1.63)\end{array}$ & $\begin{array}{c}16.146^{* *} \\
(2.34)\end{array}$ & $\begin{array}{c}2.75 * * * \\
(3.07)\end{array}$ & $\begin{array}{c}1.963^{* * *} \\
(2.92)\end{array}$ & $\begin{array}{c}3.148^{* * *} \\
(3.94)\end{array}$ & $\begin{array}{c}1.960 * * * \\
(3.93)\end{array}$ & $\begin{array}{c}1.118^{* *} \\
(2.28)\end{array}$ & $\begin{array}{c}2.210^{* * *} \\
(4.28)\end{array}$ \\
\hline \multicolumn{10}{|l|}{$\begin{array}{l}\text { Domestic Factors } \\
\text { Financial depth }\end{array}$} \\
\hline Bond & $\begin{array}{c}0.022 * * \\
(1.95)\end{array}$ & & & $\begin{array}{c}0.008^{* *} \\
(2.15)\end{array}$ & & & $\begin{array}{c}0.012 * * * \\
(3.13)\end{array}$ & & \\
\hline Pcredit & & $\begin{array}{l}0.011 \\
(1.59)\end{array}$ & & & $\begin{array}{c}0.016^{* * *} \\
(3.98)\end{array}$ & & & $\begin{array}{c}0.013^{* * *} \\
(4.08)\end{array}$ & \\
\hline M_cap & & & $\begin{array}{l}0.008 \\
(1.21)\end{array}$ & & & $\begin{array}{l}0.001 \\
(0.27)\end{array}$ & & & $\begin{array}{l}0.005 \\
(1.56)\end{array}$ \\
\hline Capital controls & $\begin{array}{l}0.844^{*} \\
(1.65)\end{array}$ & $\begin{array}{c}1.056^{* *} \\
(1.93)\end{array}$ & $\begin{array}{c}0.989 * \\
(1.63)\end{array}$ & $\begin{array}{l}0.263 \\
(0.14)\end{array}$ & $\begin{array}{l}-0.168 \\
(-0.08)\end{array}$ & $\begin{array}{l}-0.345 \\
(-0.24)\end{array}$ & $\begin{array}{c}0.904 * * \\
(2.02)\end{array}$ & $\begin{array}{l}1.060 * \\
(1.90)\end{array}$ & $\begin{array}{l}0.495 \\
(0.99)\end{array}$ \\
\hline Public debt & $\begin{array}{l}-0.056^{* * * *} \\
(-3.69)\end{array}$ & $\begin{array}{c}-0.051^{* * * *} \\
(-4.84)\end{array}$ & $\begin{array}{c}-0.041^{* * *} \\
(-4.32)\end{array}$ & $\begin{array}{c}-0.022 * * * \\
(-2.63)\end{array}$ & $\begin{array}{l}-0.007 \\
(-0.67)\end{array}$ & $\begin{array}{c}-0.015^{*} \\
(-1.81)\end{array}$ & $\begin{array}{c}-0.029^{* * * *} \\
(-4.38)\end{array}$ & $\begin{array}{c}-0.023^{* * * *} \\
(-2.52)\end{array}$ & $\begin{array}{c}-0.021^{* * *} \\
(-3.09)\end{array}$ \\
\hline Observations & 629 & 651 & 674 & 844 & 851 & 964 & 1473 & 1502 & 1638 \\
\hline
\end{tabular}

Notes: (1) Figures in parentheses are $z$-values; (2) significance at 1\%, 5\%, and 10\% is indicated by ***,**, and *; (3) sample period is 1995 Q1-2011 Q4. 
International reserves and real exchange-rate overvaluation are also related to capital flows and economic crises. International reserves are accumulated as a buffer stock against sudden outflows of foreign capital (Edwards [36]). Meanwhile, countries with an overvalued real exchange rate tend to accumulate current account deficits and foreign debt, and the possibility of sudden bond-led stop episodes increases as a result of a sharp rise in the real exchange rate (Calvo et al. [33]). Thus, we expect countries with larger international reserves or less overvaluation of the real exchange rate to be less likely to experience stops in bond inflows. We measured international reserve (Reserve) as a share of GDP and real exchange-rate overvaluation $(R E X)$ as the cumulative deviations from the long-run trend of the real exchange rate over the preceding 12 quarters. REX is defined such that it is negative (positive) when the real exchange rate is overvalued (undervalued).

The final additional domestic variable was the exchange-rate regime (Peg). Most empirical studies have found that countries with less flexible exchange-rate regimes are more susceptible to macroeconomic vulnerabilities, and thus also to crises, than those with pure floats. The reason for this is that less flexible regimes are associated with real exchange-rate overvaluation and large external imbalances due to slower adjustments of current account balances (Berger and Nitsch [54], Ghosh et al. [55]), as well as with excessive balance sheet exposures due to the implicit exchange-rate guarantee (Milesi-Ferretti and Tille [10], Magud et al. [56], Magud and Vesperoni [57]). For example, Magud et al. [56] and Magud and Vesperoni [57] found that a lack of exchange-rate flexibility is related to a higher share of private credit in foreign currency and makes the economy more vulnerable to reversals in capital flows. Additionally, Ghosh et al. [58] found that macroeconomic and financial vulnerabilities are greater under less flexible exchange-rate regimes (including hard pegs) compared to pure floats: Hard pegs are more prone to growth collapses, while intermediate regimes are the most susceptible to banking and currency crises. On the other hand, some previous studies have shown different empirical results concerning exchange-rate regimes. For example, Chinn and Wei [59] found that the nominal exchange-rate regime is irrelevant to external balance adjustment. Esaka [60] argued that countries with pegged regimes can avoid speculative attacks and currency crises, since such regimes enhance the credibility of their currencies. For extreme capital flow episodes, the literature has mainly focused on the relationship between the exchange-rate regime and capital inflow surges. For example, Ghosh et al. [6] and Mendoza and Terrones [61] found that the likelihood of large capital inflows was lower for EMEs with more flexible regimes. In order to investigate the role of the exchange-rate regime in bond-led stops, we used the de facto exchange-rate classification of Shambaugh [62], which uses a binary coding of 1 for pegged exchange-rate regimes and 0 for nonpegged regimes.

The sources and definitions of these additional domestic variables are presented in Table S1. We added these five domestic variables one by one to the baseline equation. Additionally, all variables were one-quarter lagged. The results are shown in Table 4 , where financial depth is measured by bond market capitalization. We do not report the estimation results for advanced economies in Table 4, since they were identical to those of the full sample in terms of the statistical significance of the new domestic variables. We found that after adding each new domestic variable, the signs and significances remained intact for all baseline control variables. Regarding the new domestic variables, we observed that real exchange-rate overvaluation significantly increased the probability of stops in bond flows initiated by foreign investors regardless of country groupings. On the other hand, institutional quality and the exchange-rate regime were significantly correlated with such episodes: However, only for EMEs. The results indicate that EMEs with better institutional quality and flexible exchange-rate regimes were less likely to experience stops in bond flows. Previous empirical studies, such as Fratzscher et al. [21] and Fratzscher [38], also uncovered a negative relationship between institutional quality and extreme capital flow episodes in samples of EMEs. Additionally, our estimation results indicate that EMEs with pegged exchange-rate regimes were more likely to experience bond-led stop episodes. More robustness checks on the role of the exchange-rate regime in causing stops in bond flows will be performed in the next subsection. 
Table 4. Additional domestic control variables

\begin{tabular}{|c|c|c|c|c|c|c|c|c|c|c|c|c|}
\hline & \multicolumn{6}{|c|}{ Emerging Economies } & \multicolumn{6}{|c|}{ All Economies } \\
\hline & (1) & (2) & (3) & (4) & (5) & (6) & (7) & (8) & (9) & (10) & (11) & (12) \\
\hline \multicolumn{13}{|l|}{ Global Factors } \\
\hline VIX & $\begin{array}{c}0.026^{* *} \\
(2.04)\end{array}$ & $\begin{array}{c}0.026^{* *} \\
(1.99)\end{array}$ & $\begin{array}{c}0.026^{* *} \\
(2.01)\end{array}$ & $\begin{array}{c}0.026^{* *} \\
(2.03)\end{array}$ & $\begin{array}{c}0.022 * \\
(1.91)\end{array}$ & $\begin{array}{c}0.027 * * \\
(2.14)\end{array}$ & $\begin{array}{c}0.034^{* * *} \\
(3.76)\end{array}$ & $\begin{array}{c}0.034^{* * *} \\
(3.74)\end{array}$ & $\begin{array}{c}0.034^{* * *} \\
(3.77)\end{array}$ & $\begin{array}{c}0.034^{* * *} \\
(3.76)\end{array}$ & $\begin{array}{c}0.031^{* * *} \\
(3.60)\end{array}$ & $\begin{array}{c}0.035^{* * *} \\
(3.77)\end{array}$ \\
\hline Liquidity & 0.037 & 0.037 & 0.037 & 0.038 & 0.036 & 0.039 & 0.023 & 0.022 & 0.023 & 0.023 & 0.023 & 0.023 \\
\hline \multirow[t]{2}{*}{ Interest rate } & 0.079 & 0.081 & 0.160 & 0.061 & -0.072 & 0.055 & 0.196 & 0.222 & 0.215 & 0.193 & 0.071 & 0.195 \\
\hline & $(0.26)$ & $(0.26)$ & $(0.52)$ & $(0.21)$ & $(-0.28)$ & $(0.18)$ & $(0.86)$ & $(0.95)$ & $(0.94)$ & $(0.86)$ & $(0.33)$ & $(0.86)$ \\
\hline Growth & $\begin{array}{l}0.034 \\
(0.53)\end{array}$ & $\begin{array}{l}0.030 \\
(0.31)\end{array}$ & $\begin{array}{l}0.033 \\
(0.53)\end{array}$ & $\begin{array}{l}0.035 \\
(0.54)\end{array}$ & $\begin{array}{l}0.034 \\
(0.49)\end{array}$ & $\begin{array}{l}0.030 \\
(0.46)\end{array}$ & 0.038 & 0.031 & $\begin{array}{l}0.037 \\
(0.70)\end{array}$ & 0.037 & 0.021 & 0.039 \\
\hline \multicolumn{13}{|l|}{ Contagion } \\
\hline Regional & $\begin{array}{c}0.754^{* * *} \\
(3.29)\end{array}$ & $\begin{array}{c}0.752 * * * \\
(3.20)\end{array}$ & $\begin{array}{c}0.752 * * * \\
(3.30)\end{array}$ & $\begin{array}{c}0.763^{* * *} \\
(3.34)\end{array}$ & $\begin{array}{c}0.701 * * \\
(2.84)\end{array}$ & $\begin{array}{c}0.763 \text { *** } \\
(3.34)\end{array}$ & $\begin{array}{c}0.553^{* * *} \\
(2.94)\end{array}$ & $\begin{array}{c}0.548^{* * *} \\
(2.86)\end{array}$ & $\begin{array}{c}0.571^{* * *} \\
(3.08)\end{array}$ & $\begin{array}{c}0.555^{* * *} \\
(3.02)\end{array}$ & $\begin{array}{c}0.488^{* * *} \\
(2.53)\end{array}$ & $\begin{array}{c}0.565^{* * *} \\
(3.12)\end{array}$ \\
\hline Trade & $\begin{array}{l}-0.025 \\
(-0.42)\end{array}$ & $\begin{array}{l}-0.002 \\
(-0.03)\end{array}$ & $\begin{array}{l}-0.047 \\
(-0.81)\end{array}$ & $\begin{array}{l}-0.022 \\
(-0.39)\end{array}$ & $\begin{array}{l}-0.033 \\
(-0.54)\end{array}$ & $\begin{array}{l}-0.044 \\
(-0.73)\end{array}$ & $\begin{array}{l}-0.085 \\
(-1.04)\end{array}$ & $\begin{array}{l}-0.056 \\
(-0.69)\end{array}$ & $\begin{array}{l}-0.109 \\
(-1.23)\end{array}$ & $\begin{array}{l}-0.081 \\
(-1.00)\end{array}$ & $\begin{array}{l}-0.112 \\
(-1.43)\end{array}$ & $\begin{array}{l}-0.079 \\
(-1.13)\end{array}$ \\
\hline Financial & $\begin{array}{c}18.917^{* * *} \\
(6.13)\end{array}$ & $\begin{array}{c}18.540^{* * *} \\
(5.78)\end{array}$ & $\begin{array}{c}19.643^{* * *} \\
(5.34)\end{array}$ & $\begin{array}{c}19.225^{* * *} \\
(5.98)\end{array}$ & $\begin{array}{c}18.079 * * * \\
(5.68)\end{array}$ & $\begin{array}{c}18.538^{* * *} \\
(5.93)\end{array}$ & $\begin{array}{c}1.017^{* * *} \\
(3.78)\end{array}$ & $\begin{array}{c}1.006^{* * *} \\
(3.74)\end{array}$ & $\begin{array}{c}1.0506^{* * *} \\
(3.75)\end{array}$ & $\begin{array}{c}0.991 * * * \\
(3.93)\end{array}$ & $\begin{array}{c}0.903^{* * *} \\
(3.56)\end{array}$ & $\begin{array}{c}1.104^{* * *} \\
(3.19)\end{array}$ \\
\hline \multicolumn{13}{|l|}{ Domestic Factors } \\
\hline Financial depth & $\begin{array}{c}0.003^{* *} \\
(2.02)\end{array}$ & $\begin{array}{c}0.003 * * \\
(2.38)\end{array}$ & $\begin{array}{c}0.005^{* * *} \\
(2.82)\end{array}$ & $\begin{array}{c}0.004^{* * *} \\
(2.94)\end{array}$ & $\begin{array}{c}0.003^{* *} \\
(2.00)\end{array}$ & $\begin{array}{c}0.003 * * \\
(2.01)\end{array}$ & $\begin{array}{c}0.005^{* * *} \\
(4.19)\end{array}$ & $\begin{array}{c}0.005^{* * *} \\
(4.23)\end{array}$ & $\begin{array}{c}0.005^{* * *} \\
(3.96)\end{array}$ & $\begin{array}{c}0.005^{* * *} \\
(4.01)\end{array}$ & $\begin{array}{c}0.004^{* * *} \\
(3.05)\end{array}$ & $\begin{array}{c}0.005^{* * *} \\
(4.06)\end{array}$ \\
\hline Capital controls & $\begin{array}{c}0.741^{* * *} \\
(3.59)\end{array}$ & $\begin{array}{c}0.700^{* * *} \\
(3.42)\end{array}$ & $\begin{array}{c}0.846^{* * *} \\
(3.42)\end{array}$ & $\begin{array}{c}0.797^{* * *} \\
(3.28)\end{array}$ & $\begin{array}{c}0.658^{*} \\
(2.67)\end{array}$ & $\begin{array}{c}0.699 * * * \\
(3.16)\end{array}$ & $\begin{array}{l}0.225 \\
(0.92)\end{array}$ & $\begin{array}{l}0.192 \\
(0.79)\end{array}$ & $\begin{array}{c}0.94 \\
(0.30)\end{array}$ & $\begin{array}{l}0.274 \\
(0.95)\end{array}$ & $\begin{array}{l}-0.028 \\
(-0.09)\end{array}$ & $\begin{array}{l}0.178 \\
(0.65)\end{array}$ \\
\hline \multirow[t]{4}{*}{ Public debt } & $\begin{array}{c}-0.024^{* * *} \\
(-2.79)\end{array}$ & $\begin{array}{c}-0.023^{* * *} \\
(-2.90)\end{array}$ & $\begin{array}{c}-0.028^{* * *} \\
(-2.62)\end{array}$ & $\begin{array}{c}-0.024^{* * *} \\
(-2.82)\end{array}$ & $\begin{array}{c}-0.024^{* *} \\
(-3.12)\end{array}$ & $\begin{array}{c}-0.024^{* * *} \\
(-2.72)\end{array}$ & $\begin{array}{c}-0.007^{*} \\
(-1.91)\end{array}$ & $\begin{array}{c}-0.007^{*} \\
(-1.95)\end{array}$ & $\begin{array}{c}-0.007^{* *} \\
(-2.00)\end{array}$ & $\begin{array}{c}-0.007^{*} \\
(-1.86)\end{array}$ & $\begin{array}{c}-0.006^{*} \\
(-1.67)\end{array}$ & $\begin{array}{l}-0.007^{*} \\
(-1.86)\end{array}$ \\
\hline & & G_Shock & Quality & Reserve & $R E X$ & Peg & & G_Shock & Quality & Reserve & $R E X$ & Peg \\
\hline & & -0.001 & $-0.026^{*}$ & -0.005 & $-0.750^{* *}$ & $0.440^{*}$ & & 0.006 & -0.008 & -0.002 & $-0.904 * * *$ & -0.127 \\
\hline & & $(-0.02)$ & $(-1.67)$ & $(-0.55)$ & $(-2.41)$ & $(1.71)$ & & $(0.17)$ & $(-0.80)$ & $(-0.26)$ & $(-4.39)$ & $(-0.54)$ \\
\hline Observations & 629 & 620 & 629 & 629 & 629 & 629 & 1473 & 1473 & 1473 & 1473 & 1473 & 1473 \\
\hline
\end{tabular}

Notes: (1) Figures in parentheses are $z$-values; (2) significance at $1 \%, 5 \%$, and $10 \%$ is indicated by ***,,$*$, and *; (3) sample period is 1995 Q1-2011 Q4; (4) G_Shock = domestic growth shock, Quality

$=$ institutional quality, Reserve $=$ international reserve, $R E X=$ real exchange-rate overvaluation, $P e g=$ exchange-rate regime $(P e g=1$ if the exchange-rate regime is fixed, and $P e g=0$ otherwise. . 
Finally, for both country groups, neither domestic growth shock nor international reserves were found to be statistically significant. The results imply that bond inflows are not procyclical, contrary to loan flows (Baek and Song [4]) and aggregate capital flows (Forbes and Warnock [9]). EMEs, including East Asian countries, have been accumulating international reserves over the last two decades in order to prevent large capital outflows from leading to currency and financial crises. Some previous studies have shown that international reserves play a positive role in preventing stops in capital flows and economic crises (Edwards [36], Alberola et al. [63], Bussière et al. [64]). However, our results indicate that holding large international reserves did not guarantee that EMEs could avoid stops in bond flows, despite the fact that our sample covered a relatively small number of EMEs.

\subsection{Capital Controls and Exchange-Rate Regimes}

The results of our baseline regression show that EMEs with greater capital controls or fixed exchange-rate regimes were more prone to stop episodes. Since no consensus exists in the literature on their relationship with extreme capital flow episodes, we investigate these results more closely in this subsection.

To further investigate the role of capital controls in bond-led stops, we used the additional capital control measures of Fernandez et al. [50], that is, overall restriction indices for capital inflows (Kai) and capital outflows (Kao). The combined overall restriction index $(K a)$, which considers both inflows and outflows and is an average of Kai and Kao, was used for baseline estimation. We also employed restriction indices for bonds with an original maturity of more than one year, which comprise restrictions on inflows (Boi) and outflows (Boo), and their average value (Bo). The values of Kai and Kao lie between 0 and 1, with a higher value denoting greater controls. The values of $B o i$ and $B o o$ are 0, 1/2, or 1 , where 0 means no restrictions and 1 represents greater intensity of controls than an entry of $1 / 2$.

Table 5 presents the pooled regression results with additional capital control measures for the sample of EMEs and all economies. The results for advanced economies were consistent with those for the full sample and are therefore not reported in order to save space. The results in Table 5 indicate that capital controls were not relevant to the bond-led stops of advanced economies, but were relevant to those of EMEs, as was also shown in the baseline results. While none of the six capital control measures were significant for the sample of advanced economies, four of them showed statistical significance and positive signs of coefficients for the sample of EMEs. This confirms that the probability of bond-led stops rose significantly with greater capital controls in EMEs. Table 5 also indicates that, in EMEs, overall restrictions on capital movements across borders were more important than restrictions on the bond flow itself in explaining the likelihood of bond-led stop episodes. Our estimation results show that bond-led stops were significantly correlated with the overall restrictions on both inflows (Kai) and outflows (Kao), as well as with the combined overall restriction $(K a)$. However, such stops had a significant relationship only with restrictions on bond inflow (Boi) (i.e., not with restrictions on bond outflow (Boo)).

We also performed robustness checks to assess the role of exchange-rate regimes in bond-led stops. For this purpose, we applied the exchange-rate regime classifications of Ghosh et al. [58] (hereafter Ghosh) in addition to those of Shambaugh [62] (hereafter Shambaugh), which were used to generate the results in Table 4. Ghosh et al. [58] provided seven-way fine classifications, namely hard pegs, conventional pegs, basket pegs, pegs within horizontal bands, crawling arrangements, managed floats, and free floats. By combining these seven regimes, they also generated three-way coarse classifications: Fixed, intermediate, and floating. The Ghosh classification comprised both de facto and de jure regime classifications. We assigned numbers from 1 to 7 to the fine classifications and numbers from 1 to 3 to the coarse classifications depending on the flexibility of exchange-rate regimes. Higher values denote more flexible regimes. 
Table 5. Capital controls

\begin{tabular}{|c|c|c|c|c|c|c|c|c|c|c|c|c|}
\hline & \multicolumn{6}{|c|}{ Emerging Economies } & \multicolumn{6}{|c|}{ All Economies } \\
\hline & (1) & (2) & (3) & (4) & (5) & (6) & (1) & (2) & (3) & (4) & (5) & (6) \\
\hline \multicolumn{13}{|l|}{ Global Factors } \\
\hline VIX & $\begin{array}{c}0.026^{* *} \\
(2.04)\end{array}$ & $\begin{array}{l}0.026^{*} \\
(1.92)\end{array}$ & $\begin{array}{c}0.027 * * \\
(2.14)\end{array}$ & $\begin{array}{c}0.027^{* *} \\
(2.14)\end{array}$ & $\begin{array}{c}0.027 * * \\
(2.15)\end{array}$ & $\begin{array}{c}0.029 * * \\
(2.20)\end{array}$ & $\begin{array}{c}0.034^{* * *} \\
(3.76)\end{array}$ & $\begin{array}{c}0.034^{* * *} \\
(3.75)\end{array}$ & $\begin{array}{c}0.034^{* * *} \\
(3.75)\end{array}$ & $\begin{array}{c}0.034^{* * *} \\
(3.77)\end{array}$ & $\begin{array}{c}0.034^{* * *} \\
(3.76)\end{array}$ & $\begin{array}{c}0.034^{* * *} \\
(3.77)\end{array}$ \\
\hline \multirow[t]{2}{*}{ Liquidity } & 0.037 & 0.038 & 0.037 & 0.038 & 0.037 & 0.038 & 0.023 & 0.023 & 0.023 & 0.023 & 0.023 & 0.023 \\
\hline & $(0.96)$ & $(0.96)$ & $(0.96)$ & $(0.97)$ & $(0.97)$ & $(0.97)$ & $(0.94)$ & $(0.94)$ & $(0.94)$ & $(0.93)$ & $(0.93)$ & $(0.93)$ \\
\hline \multirow[t]{2}{*}{ Interest rate } & 0.079 & 0.035 & 0.105 & 0.114 & 0.118 & 0.120 & 0.196 & 0.190 & 0.200 & 0.187 & 0.187 & 0.186 \\
\hline & $(0.26)$ & $(0.11)$ & $(0.35)$ & $(0.39)$ & $(0.39)$ & $(0.40)$ & $(0.86)$ & $(0.83)$ & $(0.88)$ & $(0.82)$ & $(0.82)$ & $(0.81)$ \\
\hline \multirow[t]{2}{*}{ Growth } & 0.034 & 0.038 & 0.031 & 0.031 & 0.034 & 0.028 & 0.038 & 0.037 & 0.037 & 0.036 & 0.036 & 0.036 \\
\hline & $(0.53)$ & $(0.61)$ & $(0.48)$ & $(0.48)$ & $(0.54)$ & $(0.44)$ & $(0.70)$ & $(0.70)$ & $(0.70)$ & $(0.67)$ & $(0.67)$ & $(0.66)$ \\
\hline \multicolumn{13}{|l|}{ Contagion } \\
\hline Regional & $\begin{array}{c}0.754^{* * *} \\
(3.29)\end{array}$ & $\begin{array}{c}0.729 * * * \\
(2.99)\end{array}$ & $\begin{array}{c}0.760^{* * *} \\
(3.34)\end{array}$ & $\begin{array}{c}0.747^{* * *} \\
(3.25)\end{array}$ & $\begin{array}{c}0.756^{* * *} \\
(3.24)\end{array}$ & $\begin{array}{c}0.744^{* * *} \\
(3.19)\end{array}$ & $\begin{array}{c}0.553^{* * *} \\
(2.94)\end{array}$ & $\begin{array}{c}0.550 * * * \\
(2.92)\end{array}$ & $\begin{array}{c}0.555^{* * *} \\
(2.96)\end{array}$ & $\begin{array}{c}0.546^{* * *} \\
(2.93)\end{array}$ & $\begin{array}{c}0.546^{* * *} \\
(2.92)\end{array}$ & $\begin{array}{c}0.546^{* * *} \\
(2.94)\end{array}$ \\
\hline \multirow[t]{2}{*}{ Trade } & -0.025 & -0.005 & -0.049 & -0.057 & -0.048 & -0.075 & -0.085 & -0.089 & -0.084 & -0.096 & -0.096 & -0.097 \\
\hline & $(-0.42)$ & $(-0.08)$ & $(-0.78)$ & $(-0.94)$ & $(-0.94)$ & $(-1.11)$ & $(-1.04)$ & $(-1.06)$ & $(-1.04)$ & $(-1.20)$ & $(-1.19)$ & $(-1.21)$ \\
\hline Financial & $\begin{array}{c}18.917^{* * *} \\
(6.13)\end{array}$ & $\begin{array}{c}20.104^{* * *} \\
(5.70)\end{array}$ & $\begin{array}{c}17.954^{* * *} \\
(6.20)\end{array}$ & $\begin{array}{c}18.237^{* * *} \\
(5.87)\end{array}$ & $\begin{array}{c}18.666^{* * * *} \\
(5.86)\end{array}$ & $\begin{array}{c}17.228^{* * *} \\
(5.63)\end{array}$ & $\begin{array}{c}1.017^{* * * *} \\
(3.78)\end{array}$ & $\begin{array}{c}0.994^{* * * *} \\
(3.69)\end{array}$ & $\begin{array}{c}1.029 * * * \\
(3.77)\end{array}$ & $\begin{array}{c}0.972 * * * \\
(3.54)\end{array}$ & $\begin{array}{c}0.970 * * * \\
(3.54)\end{array}$ & $\begin{array}{c}0.970 * * * \\
(3.38)\end{array}$ \\
\hline \multicolumn{13}{|l|}{ Domestic Factors } \\
\hline Financial depth & $\begin{array}{c}0.003^{* *} \\
(2.02)\end{array}$ & $\begin{array}{c}0.004^{* * *} \\
(2.70)\end{array}$ & $\begin{array}{c}0.003 * \\
(1.67)\end{array}$ & $\begin{array}{c}0.003 * \\
(1.73)\end{array}$ & $\begin{array}{c}0.004^{* * *} \\
(2.79)\end{array}$ & $\begin{array}{c}0.003 * \\
(1.69)\end{array}$ & $\begin{array}{c}0.005^{* * *} \\
(4.19)\end{array}$ & $\begin{array}{c}0.005^{* * *} \\
(4.18)\end{array}$ & $\begin{array}{c}0.005^{* * * *} \\
(4.11)\end{array}$ & $\begin{array}{c}0.005^{* * *} \\
(4.04)\end{array}$ & $\begin{array}{c}0.005^{* * * *} \\
(4.12)\end{array}$ & $\begin{array}{c}0.005^{* * *} \\
(4.02)\end{array}$ \\
\hline Public debt & $\begin{array}{c}-0.024^{* * *} \\
(-2.79) \\
\end{array}$ & $\begin{array}{c}-0.026^{* * *} \\
(-2.71)\end{array}$ & $\begin{array}{c}-0.022 * * * \\
(-2.88)\end{array}$ & $\begin{array}{c}-0.022 * * * \\
(-2.76)\end{array}$ & $\begin{array}{c}-0.023 * * * \\
(-2.75)\end{array}$ & $\begin{array}{c}-0.020^{* * *} \\
(-3.03)\end{array}$ & $\begin{array}{c}-0.007 * \\
(-1.91) \\
\end{array}$ & $\begin{array}{c}-0.007 * \\
(-1.95) \\
\end{array}$ & $\begin{array}{c}-0.007 * \\
(-1.90) \\
\end{array}$ & $\begin{array}{c}-0.007^{* *} \\
(-1.99) \\
\end{array}$ & $\begin{array}{c}-0.007^{* *} \\
(-1.99) \\
\end{array}$ & $\begin{array}{c}-0.007 \text { * } \\
(-2.00)\end{array}$ \\
\hline \multirow[t]{3}{*}{ Capital controls } & $K a$ & Kai & Kao & Bo & Boi & Boo & Ka & Kai & Kao & Bo & Boi & Boo \\
\hline & $0.741^{* * *}$ & $1.135^{* * *}$ & 0.367 * & 0.334 & $0.516^{*}$ & 0.033 & 0.225 & 0.196 & 0.203 & 0.018 & 0.028 & 0.005 \\
\hline & (3.59) & $(4.21)$ & $(1.72)$ & $(1.25)$ & $(2.03)$ & $(0.14)$ & $(0.92)$ & $(0.69)$ & $(0.97)$ & $(0.09)$ & $(0.13)$ & $(0.03)$ \\
\hline Observations & 629 & 629 & 629 & 629 & 629 & 629 & 1473 & 1473 & 1473 & 1473 & 1473 & 1473 \\
\hline
\end{tabular}


Table 6 presents estimation results for the exchange-rate regime classifications of Shambaugh and Ghosh for the sample of EMEs. We did not consider the sample of advanced economies, since the exchange-rate regime variable showed no significance in Table 4 . As a capital control measure, the overall restriction index of $\mathrm{Ka}$ was used. The estimation results for the Shambaugh and Ghosh classifications of exchange-rate regimes are reported in Column (1) and Columns (2)-(5), respectively. It was found that all exchange-rate regime variables had negative and significant coefficients, indicating that the likelihood of bond-led stops decreased when exchange-rate regimes were more flexible. Furthermore, we employed regime dummies for the coarse classification (fixed, intermediate, and floating) of Ghosh, where a floating regime was used as a reference. The results in Columns (6) and (7) imply that EMEs with fixed regimes were more likely to have stop episodes in bond flows than those with floating regimes. Meanwhile, we found no statistical difference between intermediate and floating regimes in determining the probability of bond-led stops.

Additionally, we investigated cases of other combinations of capital control measures and exchange-rate regimes. We used three overall restriction indices $(\mathrm{Ka}, \mathrm{Kai}$, and $\mathrm{Kao})$ and two classifications (the Ghosh coarse de facto and Shambaugh) for exchange-rate regimes. The results presented in Table 7 confirm that the probability of bond-led stops was significantly reduced with lower capital controls or with more flexible exchange-rate regimes. An exception was that the statistical significance of capital controls on outflows became weak when Shambaugh's classification was used as a control variable (Column (6)).

Finally, we examined the combined effect of capital controls and exchange-rate regimes on bond-led stops. We divided overall capital flow restrictions into two types, high and low, and matched them with each of two classifications of the exchange-rate regime (the Ghosh coarse de facto and Shambaugh) to construct new dummy variables. First, using the Ghosh classifications of exchange-rate regimes, we defined a new dummy as follows: Regime $_{i j}=1$ if $K a=i$ and Ghosh's regime $=j$, and 0 otherwise; for $i, 1=$ low $(0 \leq K a \leq 0.5), 2=$ high $(0.5<K a \leq 1)$; and for $j, 1=$ fixed, 2 = intermediate, and 3 = floating. For example, Regime 21 denotes the dummy variable for a fixed regime with high restrictions on overall capital flows. It is defined identically for controls on inflows (Kai) and outflows $(\mathrm{Kao})$. The estimation results for the sample of EMEs are shown in Columns (1), (3), and (5) in Table 8. Next, a similar method was used to construct the dummies for the Shambaugh regimes. Low_Peg (High_Peg) denotes the dummy variable for a pegged exchange-rate regime with low (high) restrictions on capital flows, whereas Low_Nonpeg (High_Nonpeg) is the dummy variable for a nonpegged regime with low (high) restrictions. The results of estimating these dummy variables are presented in Columns (2), (4), and (6) in Table 8. In the estimation, Regime $_{13}$ (the dummy of a floating regime with low capital controls) and Low_Nonpeg (the dummy of a nonpegged regime with low capital controls) were used as reference dummies for the classifications of Ghosh and Shambaugh, respectively. These benchmark dummies corresponded to a regime with low capital controls and a relatively flexible (or floating) exchange-rate system. 
Table 6. Exchange-rate regimes: Emerging economies.

\begin{tabular}{|c|c|c|c|c|c|c|c|}
\hline & (1) & (2) & (3) & (4) & (5) & (6) & (7) \\
\hline \multicolumn{8}{|l|}{ Global Factors } \\
\hline VIX & $\begin{array}{c}0.027^{* *} \\
(2.14)\end{array}$ & $\begin{array}{c}0.027 * * \\
(2.05)\end{array}$ & $\begin{array}{c}0.026^{* *} \\
(1.99)\end{array}$ & $\begin{array}{c}0.027^{* *} \\
(2.10)\end{array}$ & $\begin{array}{c}0.026^{* *} \\
(1.99)\end{array}$ & $\begin{array}{c}0.026^{* *} \\
(1.99)\end{array}$ & $\begin{array}{c}0.026^{* *} \\
(2.09)\end{array}$ \\
\hline \multirow[t]{2}{*}{ Liquidity } & 0.039 & 0.039 & 0.039 & 0.040 & 0.039 & 0.039 & 0.039 \\
\hline & $(1.00)$ & $(0.98)$ & $(1.00)$ & $(1.00)$ & $(1.00)$ & $(1.00)$ & $(1.00)$ \\
\hline \multirow{2}{*}{ Interest rate } & 0.056 & 0.062 & 0.082 & 0.027 & 0.082 & 0.119 & 0.024 \\
\hline & $(0.18)$ & $(0.21)$ & $(0.27)$ & $(0.09)$ & $(0.27)$ & $(0.34)$ & $(0.08)$ \\
\hline \multirow[t]{2}{*}{ Growth } & 0.030 & 0.030 & 0.031 & 0.029 & 0.031 & 0.032 & 0.034 \\
\hline & $(0.46)$ & $(0.46)$ & $(0.48)$ & $(0.45)$ & $(0.48)$ & $(0.49)$ & $(0.52)$ \\
\hline \multicolumn{8}{|l|}{ Contagion } \\
\hline Regional & $\begin{array}{c}0.763 * * * \\
(3.34)\end{array}$ & $\begin{array}{c}0.758^{* * *} \\
(3.32)\end{array}$ & $\begin{array}{c}0.777^{* * *} \\
(3.34)\end{array}$ & $\begin{array}{c}0.759^{* * *} \\
(3.31)\end{array}$ & $\begin{array}{c}0.777^{* * *} \\
(3.34)\end{array}$ & $\begin{array}{c}0.770^{* * *} \\
(3.31)\end{array}$ & $\begin{array}{c}0.767^{* * * *} \\
(3.49)\end{array}$ \\
\hline Trade & $\begin{array}{l}-0.044 \\
(-0.73)\end{array}$ & $\begin{array}{l}-0.031 \\
(-0.51)\end{array}$ & $\begin{array}{l}-0.055 \\
(-0.88)\end{array}$ & $\begin{array}{l}-0.023 \\
(-0.39)\end{array}$ & $\begin{array}{l}-0.055 \\
(-0.88)\end{array}$ & $\begin{array}{l}-0.059 \\
(-0.85)\end{array}$ & $\begin{array}{l}-0.023 \\
(-039)\end{array}$ \\
\hline Financial & $\begin{array}{c}18.538^{* * *} \\
(5.93)\end{array}$ & $\begin{array}{c}17.942^{* * *} \\
(5.83)\end{array}$ & $\begin{array}{c}17.892^{* * *} \\
(5.77)\end{array}$ & $\begin{array}{c}17.409^{* * *} \\
(4.99)\end{array}$ & $\begin{array}{c}17.892^{* * *} \\
(5.77)\end{array}$ & $\begin{array}{c}18.036^{* * *} \\
(5.67)\end{array}$ & $\begin{array}{c}18.125^{* * *} \\
(5.31)\end{array}$ \\
\hline \multicolumn{8}{|l|}{ Domestic Factors } \\
\hline Financial depth & $\begin{array}{c}0.003 \text { ** } \\
(2.01)\end{array}$ & $\begin{array}{c}0.004 * * \\
(2.23)\end{array}$ & $\begin{array}{c}0.004^{* * *} \\
(2.62)\end{array}$ & $\begin{array}{c}0.003 * \\
(1.96)\end{array}$ & $\begin{array}{c}0.004^{* * *} \\
(2.62)\end{array}$ & $\begin{array}{c}0.004^{* * *} \\
(2.77)\end{array}$ & $\begin{array}{c}0.003 * \\
(1.85)\end{array}$ \\
\hline Capital controls & $\begin{array}{c}0.699 * * * \\
(3.16)\end{array}$ & $\begin{array}{c}0.736^{* * *} \\
(3.56)\end{array}$ & $\begin{array}{c}0.662 * * * \\
(2.89)\end{array}$ & $\begin{array}{c}0.710^{* * *} \\
(3.44)\end{array}$ & $\begin{array}{c}0.662 * * * \\
(2.89)\end{array}$ & $\begin{array}{c}0.680 * * * \\
(3.01)\end{array}$ & $\begin{array}{c}0.675^{* * *} \\
(3.13)\end{array}$ \\
\hline \multirow[t]{2}{*}{ Public debt } & $\begin{array}{c}-0.024^{* * *} \\
(-2.72)\end{array}$ & $\begin{array}{c}-0.024^{* * *} \\
(-2.77)\end{array}$ & $\begin{array}{c}-0.024^{* * *} \\
(-2.81)\end{array}$ & $\begin{array}{c}-0.023^{* * *} \\
(-2.60)\end{array}$ & $\begin{array}{c}-0.024^{* * *} \\
(-2.81)\end{array}$ & $\begin{array}{c}-0.024^{* * *} \\
(-2.79)\end{array}$ & $\begin{array}{c}-0.023^{* *} \\
(-2.54)\end{array}$ \\
\hline & Shambaugh & Ghosh & Ghosh & Ghosh & Ghosh & Ghosh & Ghosh \\
\hline Exchange-rate regimes & $\begin{array}{c}\mathrm{Peg} \\
0.440 * \\
(1.71)\end{array}$ & $\begin{array}{c}\text { De facto Fine } \\
-0.089^{* * *} \\
(-2.85)\end{array}$ & $\begin{array}{c}\text { De facto Coarse } \\
-0.322^{* *} \\
(-2.24)\end{array}$ & $\begin{array}{c}\text { De jure Fine } \\
-0.116^{*} \\
(-1.94)\end{array}$ & $\begin{array}{c}\text { De jure Coarse } \\
-0.322^{* *} \\
(-2.24)\end{array}$ & $\begin{array}{c}\text { De facto Fixed } \\
0.480 * * \\
(2.37) \\
\text { Intermediate } \\
0.370 \\
(1.45)\end{array}$ & $\begin{array}{c}\text { De jure Fixed } \\
0.608^{* *} \\
(2.18) \\
\text { Intermediate } \\
0.058 \\
(0.16)\end{array}$ \\
\hline Observations & 629 & 629 & 629 & 629 & 629 & 629 & 629 \\
\hline
\end{tabular}

Notes: (1) Figures in parentheses are $z$-values; (2) significance at $1 \%, 5 \%$, and 10\% is indicated by ***,**, and *; (3) sample period is 1995 Q1-2011 Q4. 
Table 7. Capital controls and exchange-rate regimes: Emerging economies.

\begin{tabular}{|c|c|c|c|c|c|c|}
\hline & (1) & (2) & (3) & (4) & (5) & (6) \\
\hline \multicolumn{7}{|l|}{ Global Factors } \\
\hline VIX & $\begin{array}{l}0.026^{* *} \\
(1.99)\end{array}$ & $\begin{array}{c}0.027^{* *} \\
(2.14)\end{array}$ & $\begin{array}{l}0.025 * \\
(1.90)\end{array}$ & $\begin{array}{c}0.026^{* *} \\
(2.01)\end{array}$ & $\begin{array}{c}0.027^{* *} \\
(2.07)\end{array}$ & $\begin{array}{l}0.028^{* *} \\
(2.24)\end{array}$ \\
\hline \multirow[t]{2}{*}{ Liquidity } & 0.039 & 0.039 & 0.039 & 0.039 & 0.040 & 0.039 \\
\hline & $(1.00)$ & $(1.00)$ & $(0.99)$ & $(0.99)$ & $(1.01)$ & $(1.01)$ \\
\hline \multirow[t]{2}{*}{ Interest rate } & 0.082 & 0.055 & 0.048 & 0.021 & 0.101 & 0.074 \\
\hline & $(0.27)$ & $(0.18)$ & $(0.15)$ & $(0.07)$ & $(0.34)$ & $(0.25)$ \\
\hline \multirow[t]{2}{*}{ Growth } & 0.031 & 0.030 & 0.036 & 0.035 & 0.028 & 0.026 \\
\hline & $(0.48)$ & $(0.46)$ & $(0.56)$ & $(0.54)$ & $(0.43)$ & $(0.39)$ \\
\hline \multicolumn{7}{|l|}{ Contagion } \\
\hline Regional & $\begin{array}{c}0.777^{* * *} \\
(3.34)\end{array}$ & $\begin{array}{c}0.763 \text { *** } \\
(3.34)\end{array}$ & $\begin{array}{c}0.751^{* * *} \\
(3.09)\end{array}$ & $\begin{array}{c}0.738 \text { *** } \\
(3.05)\end{array}$ & $\begin{array}{c}0.786^{* * *} \\
(3.40)\end{array}$ & $\begin{array}{c}0.768^{* * *} \\
(3.38)\end{array}$ \\
\hline Trade & $\begin{array}{l}-0.055 \\
(-0.88)\end{array}$ & $\begin{array}{l}-0.044 \\
(-0.73)\end{array}$ & $\begin{array}{l}-0.034 \\
(-0.58)\end{array}$ & $\begin{array}{l}-0.023 \\
(-0.39)\end{array}$ & $\begin{array}{l}-0.076 \\
(-1.16)\end{array}$ & $\begin{array}{l}-0.068 \\
(-1.08)\end{array}$ \\
\hline Financial & $\begin{array}{c}17.892 * * * \\
(5.77)\end{array}$ & $\begin{array}{c}18.538^{* * *} \\
(5.93)\end{array}$ & $\begin{array}{c}19.102 * * * \\
(5.34)\end{array}$ & $\begin{array}{c}19.756^{* * *} \\
(5.44)\end{array}$ & $\begin{array}{c}16.964^{* * *} \\
(6.00)\end{array}$ & $\begin{array}{c}17.548^{* * *} \\
(6.09)\end{array}$ \\
\hline \multicolumn{7}{|l|}{ Domestic Factors } \\
\hline Financial depth & $\begin{array}{c}0.004^{* * *} \\
(2.62)\end{array}$ & $\begin{array}{c}0.003^{* *} \\
(2.01)\end{array}$ & $\begin{array}{c}0.005^{* * *} \\
(3.06)\end{array}$ & $\begin{array}{c}0.004^{* *} \\
(2.58)\end{array}$ & $\begin{array}{c}0.004^{* *} \\
(2.37)\end{array}$ & $\begin{array}{c}0.003 * \\
(1.71)\end{array}$ \\
\hline Public debt & $\begin{array}{c}-0.024^{* * *} \\
(-2.81)\end{array}$ & $\begin{array}{c}-0.024^{* * *} \\
(-2.72)\end{array}$ & $\begin{array}{c}-0.026^{* * *} \\
(-2.72)\end{array}$ & $\begin{array}{c}-0.026^{* * *} \\
(-2.65)\end{array}$ & $\begin{array}{c}-0.023^{* * * *} \\
(-2.92)\end{array}$ & $\begin{array}{c}-0.022 * * * \\
(-2.80)\end{array}$ \\
\hline \multirow[t]{2}{*}{ Capital controls } & $\mathrm{Ka}$ & $\mathrm{Ka}$ & $\mathrm{Kai}$ & $\mathrm{Kai}$ & Kao & Kao \\
\hline & $\begin{array}{c}0.662 * * * \\
(2.89)\end{array}$ & $\begin{array}{c}0.699 * * * \\
(3.16)\end{array}$ & $\begin{array}{c}0.995 * * * \\
(3.32)\end{array}$ & $\begin{array}{c}1.069 * * * \\
(3.40)\end{array}$ & $\begin{array}{l}0.355^{*} \\
(1.69)\end{array}$ & $\begin{array}{l}0.345 \\
(1.64)\end{array}$ \\
\hline \multirow[t]{3}{*}{ Exchange-rate regime } & Ghosh & Shambaugh & Ghosh & Shambaugh & Ghosh & Shambaugh \\
\hline & Coarse & Peg & Coarse & Peg & Coarse & Peg \\
\hline & $\begin{array}{c}-0.322^{* *} \\
(-2.24)\end{array}$ & $\begin{array}{c}0.439 * \\
(1.71)\end{array}$ & $\begin{array}{c}-0.265 * \\
(-1.78)\end{array}$ & $\begin{array}{c}0.377^{*} \\
(1.71)\end{array}$ & $\begin{array}{c}-0.353^{* *} \\
(-2.48)\end{array}$ & $\begin{array}{l}0.477 \\
(1.56)\end{array}$ \\
\hline Observations & 629 & 629 & 629 & 629 & 629 & 629 \\
\hline
\end{tabular}

\footnotetext{
Notes: (1) Figures in parentheses are $z$-values; (2) significance at $1 \%, 5 \%$, and $10 \%$ is indicated by $* * *$, **, and *;
} (3) sample period is $1995 \mathrm{Q} 1-2011 \mathrm{Q} 4$.

It can be seen from Table 8 that the coefficients of Regime 21 , Regime 22, and High_Peg were statistically significant and positive when the combined overall index of restrictions on capital inflows and outflows (Ka) was applied (Columns (1) and (2)). The significant dummy variables were all related to high overall capital controls. However, the dummies for high capital controls with a flexible exchange-rate regime (Regime 23 and High_Nonpeg) were not significant. The estimation result implies that the possibility of stops in bond flows was higher in EMEs with these dummies than in those with a benchmark dummy. It can also be observed that all dummy variables related to high capital restrictions had statistically significant and positive coefficients irrespective of the exchange-rate system when the index of restrictions on capital inflows (Kai) was applied (Columns (3) and (4)). This indicates that EMEs with high restrictions on capital inflows, whether or not they had a flexible exchange-rate system, were more likely to experience bond-led stops than those with low capital controls and a more flexible exchange-rate regime. On the other hand, for capital outflow restrictions (Kao) (Columns (5) and (6)), there were no statistically significant dummies, except in the case of the Shambaugh classification (High_Peg in Column (6)). It should also be noted that none of the dummies related to low restrictions on capital flows were found to be significant, regardless of the exchange-rate flexibility and type of capital flow restriction.

These results suggest that, first, the likelihood of bond-led stops was higher in EMEs with high capital controls and less flexible exchange-rate regimes than in those with low controls and flexible regimes. Second, when overall capital restrictions were high, EMEs with flexible regimes were less likely to face bond-led stops than those with less flexible regimes, as shown in Columns (1) and (2). Third, the probability of stop episodes was related to capital inflow controls rather than capital outflow controls. Finally, when capital controls were low, the choice of exchange-rate regime was 
not significantly correlated with the likelihood of stop episodes. Although we artificially divided the extent of the restrictions on capital flows, overall, our findings suggest that capital control played a greater role in predicting bond-led stop episodes of EMEs than did exchange-rate regimes. When we used the mean or median of the capital restriction index for division of capital controls, the estimation results remained virtually unchanged.

Table 8. Interaction between capital controls and exchange-rate regimes: Emerging economies.

\begin{tabular}{|c|c|c|c|c|c|c|}
\hline & (1) & (2) & (3) & (4) & (5) & (6) \\
\hline \multicolumn{7}{|l|}{ Global Factors } \\
\hline VIX & $\begin{array}{c}0.027^{* *} \\
(2.03)\end{array}$ & $\begin{array}{c}0.028^{* *} \\
(2.20)\end{array}$ & $\begin{array}{c}0.029^{* *} \\
(2.01)\end{array}$ & $\begin{array}{c}0.026^{* *} \\
(1.96)\end{array}$ & $\begin{array}{c}0.029 * * \\
(2.21)\end{array}$ & $\begin{array}{c}0.030 * * \\
(2.36)\end{array}$ \\
\hline \multirow[t]{2}{*}{ Liquidity } & 0.040 & 0.037 & 0.047 & 0.039 & 0.040 & 0.037 \\
\hline & $(0.98)$ & $(0.94)$ & (1.08) & (1.00) & $(0.98)$ & $(0.95)$ \\
\hline \multirow[t]{2}{*}{ Interest rate } & 0.140 & 0.093 & 0.067 & 0.051 & 0.150 & 0.104 \\
\hline & $(0.42)$ & $(0.31)$ & $(0.19)$ & $(0.18)$ & $(0.44)$ & $(0.33)$ \\
\hline \multirow{2}{*}{ Growth } & 0.028 & 0.029 & 0.016 & 0.024 & 0.024 & 0.024 \\
\hline & $(0.44)$ & $(0.44)$ & $(0.26)$ & $(0.40)$ & $(0.37)$ & $(0.35)$ \\
\hline \multicolumn{7}{|l|}{ Contagion } \\
\hline Regional & $\begin{array}{c}0.793^{* * *} \\
(3.24)\end{array}$ & $\begin{array}{c}0.780 * * * \\
(3.39)\end{array}$ & $\begin{array}{c}0.778^{* * *} \\
(2.90)\end{array}$ & $\begin{array}{c}0.693^{* * *} \\
(2.66)\end{array}$ & $\begin{array}{c}0.766^{* * *} \\
(3.08)\end{array}$ & $\begin{array}{c}0.749^{* * *} \\
(3.14)\end{array}$ \\
\hline Trade & -0.082 & -0.058 & -0.098 & -0.050 & -0.111 & -0.094 \\
\hline Financial & $\begin{array}{c}(-1.07 \\
17.129 * * * \\
(5.15)\end{array}$ & $\begin{array}{c}(-0.88) \\
18.038^{* * *} \\
(5.40)\end{array}$ & $\begin{array}{c}(-1.22) \\
17.850 * * * \\
(4.79)\end{array}$ & $\begin{array}{c}(-0.70) \\
19.751^{* * *} \\
(4.83)\end{array}$ & $\begin{array}{c}(-1.35) \\
16.212^{* * *} \\
(5.29)\end{array}$ & $\begin{array}{c}(-1.36) \\
16.621^{* * *} \\
(4.95)\end{array}$ \\
\hline \multicolumn{7}{|l|}{ Domestic Factors } \\
\hline Financial depth & $\begin{array}{c}0.005^{* *} \\
(2.18)\end{array}$ & $\begin{array}{c}0.004^{* *} \\
(2.12)\end{array}$ & $\begin{array}{c}0.007^{* *} \\
(3.26)\end{array}$ & $\begin{array}{c}0.004^{* *} \\
(2.53)\end{array}$ & $\begin{array}{c}0.004^{* *} \\
(2.33)\end{array}$ & $\begin{array}{c}0.003^{* *} \\
(1.51)\end{array}$ \\
\hline \multirow[t]{17}{*}{ Public debt } & $\begin{array}{c}-0.022 \text { ** } \\
(-2.43)\end{array}$ & $\begin{array}{c}-0.023^{* *} \\
(-2.44)\end{array}$ & $\begin{array}{c}-0.025^{* *} \\
(-2.37)\end{array}$ & $\begin{array}{c}-0.026^{* *} \\
(-2.34)\end{array}$ & $\begin{array}{c}-0.020^{* *} \\
(-2.66)\end{array}$ & $\begin{array}{c}-0.020^{* *} \\
(-2.53)\end{array}$ \\
\hline & $\mathrm{Ka}$ & $\mathrm{Ka}$ & Kai & Kai & Kao & Kao \\
\hline & Regime $_{21}$ & High_Peg & Regime $_{21}$ & High_Peg & Regime $_{21}$ & High_Peg \\
\hline & 0.773 * & $0.902 * * *$ & $1.142 * * *$ & $0.958 * * *$ & 0.430 & $0.630 * *$ \\
\hline & $(1.83)$ & $(3.06)$ & $(2.82)$ & $(3.08)$ & $(1.07)$ & \\
\hline & Regime $_{22}$ & High_Nonpeg & Regime $_{22}$ & High_Nonpeg & Regime $_{22}$ & High_Nonpeg \\
\hline & $0.696^{* *}$ & 0.289 & $1.043^{* * *}$ & $0.645^{* *}$ & 0.232 & -0.206 \\
\hline & (2.13) & $(1.21)$ & $(2.81)$ & $(2.15)$ & $(0.71)$ & $(-1.05)$ \\
\hline & Regime $_{23}$ & Low_Peg & Regime $_{23}$ & Low_Peg & Regime $_{23}$ & Low_Peg \\
\hline & 0.398 & 0.161 & $1.440 * * *$ & 0.283 & -0.243 & -0.064 \\
\hline & $(0.71)$ & $(0.23)$ & (3.72) & $(0.38)$ & $(-0.63)$ & $(-0.10)$ \\
\hline & Regime $_{11}$ & & Regime $_{11}$ & & Regime $_{11}$ & \\
\hline & 0.655 & & 1.109 & & 0.319 & \\
\hline & (1.06) & & (1.60) & & $(0.58)$ & \\
\hline & Regime $_{12}$ & & Regime $_{12}$ & & Regime $_{12}$ & \\
\hline & 0.419 & & 0.823 & & 0.253 & \\
\hline & $(0.79)$ & & $(1.51)$ & & $(0.53)$ & \\
\hline Observations & 629 & 629 & 629 & 629 & 629 & 629 \\
\hline
\end{tabular}

Note: (1) Figures in parentheses are $z$-values; (2) significance at $1 \%, 5 \%$, and $10 \%$ is indicated by ***,**, and *; (3) Regime $_{i j}=1$ if $K a=i$ and Ghosh's de facto regime $=j$, and 0 otherwise. For $i, 1=$ low $(0 \leq K a \leq 0.5), 2=$ high $(0.5<K a \leq 1)$; for $j, 1=$ fixed, 2 = intermediate, 3 = floating. For Shambaugh's classification, High_Peg $=1$ for pegged exchange-rate regime with $K a=2$, and 0 otherwise. High_Nonpeg $=1$ for nonpegged regime with $K a=2$, and 0 otherwise. If $K a=1$, they become Low_Nonpeg and Low_Nonpeg, respectively. The same notation applies to Kai and Kao. Regime ${ }_{13}$ and Low_Nonpeg are used as reference dummies.

Why did capital controls increase rather than reduce a country's vulnerability to cross-border bond flows? Alternatively, why were they ineffective in preventing extreme bond flows across countries? Previous studies have offered several possible answers to these questions. For example, Kaminsky [34] and Glick et al. [44] pointed out that countries with unsound macroeconomic and political environments and weak financial systems and institutions are likely to retain capital controls, which may trigger financial crises. Additionally, Bartolini and Drazen [65] viewed capital controls as potential signals of inconsistent and poorly designed future government policies under the assumption that investors have 
imperfect information on governments' intentions. The controls intended to limit outflows may trigger more outflows since they lower investors' confidence. On the contrary, a regime of free capital mobility may signal that future policies are likely to be more favorable to investment: Thus, the removal of controls on capital outflows may generate capital inflows rather than outflows.

\section{Conclusions}

This paper empirically examined the determinants of bond-led stop episodes initiated by foreign investors. We confirmed that the factors associated with extreme capital flows varied across debt instruments and across country groups. Contrary to previous studies, we found that the probability of bond-led stops was more strongly correlated with contagion and domestic pull factors than global factors. Additionally, domestic factors were more closely related to the bond-led stop episodes of EMEs than to those of advanced economies.

To summarize the empirical results based on the EMEs and advanced economies investigated in our sample, first, global risk was the only common global factor that could predict stop episodes driven by bond flows. Previous studies have also confirmed that global risk consistently predicts all types of episodes in gross capital inflows. Second, contagion effects played an important role in the occurrence of stop episodes. Major channels were through regional and financial linkages. Third, bond-led stop episodes were more likely to occur in countries with larger financial markets or with more overvalued real exchange rates. However, country indebtedness did not seem to cause episodes.

On the other hand, we found additional domestic factors that were related to episodes in EMEs but not in advanced economies. The main policy implications of our estimation results, particularly for EMEs, are that bond-led stop episodes were less likely to occur in countries with higher levels of institutional quality, lower capital account restrictions, or more flexible exchange-rate regimes. We also found that EMEs with high capital controls and less flexible exchange-rate regimes were more likely to experience such episodes than those with low capital controls and flexible regimes. The reason for this may be that countries with high capital controls may face weak macroeconomic fundamentals and institutions with low quality and that a less flexible exchange-rate regime tends to be associated with real exchange-rate overvaluation, large external imbalances, and excessive balance sheet exposures. Thus, the best policy option to avoid stop episodes in bond flows in EMEs is to strengthen economic fundamentals and institutions, which are closely related to policy choices of structural elements such as financial openness and exchange-rate regimes. It should be noted that most advanced economies have high levels of institutional quality and impose low levels of capital control with flexible exchange-rate regimes. Finally, holding large reserves in EMEs does not mean that the sudden reversal of bond inflows initiated by foreign investors can be prevented.

A caveat is that, since our sample covered a relatively small number of EMEs, our estimation results do not necessarily apply to bond-led stop episodes in all EMEs. This restriction was mainly due to limited data availability. Our future research agenda is to clarify the heterogeneous empirical results in the existing literature relating to extreme capital flow episodes using extended datasets and to derive more robust policy implications. Future studies need to further investigate the role of capital controls and exchange-rate regimes in extreme capital flow events and capital flow volatility.

Supplementary Materials: The following are available online at http://www.mdpi.com/2071-1050/11/14/3763/s1, Table S1: Data descriptions and sources; Table S2: Country list.

Author Contributions: Conceptualization, S.-G.B. and C.-Y.S.; methodology, S.-G.B. and C.-Y.S.; software, S.-G.B. and C.-Y.S.; validation, S.-G.B.; formal analysis, S.-G.B. and C.-Y.S.; investigation, S.-G.B. and C.-Y.S.; resources, S.-G.B. and C.-Y.S.; writing-original draft preparation, S.-G.B. and C.-Y.S.; writing-review and editing, S.-G.B. and C.-Y.S.; visualization, S.-G.B. and C.-Y.S.; supervision, C.-Y.S.

Funding: This research received no external funding.

Conflicts of Interest: The authors declare no conflict of interest. 


\section{References}

1. Pagliari, M.S.; Hannan, W.A. The Volatility of Capital Flows in Emerging Markets: Measures and Determinants (No. 17/41); International Monetary Fund: Washington, DC, USA, 2017.

2. Hannan, W.A. The drivers of capital flows in emerging markets: Post global financial crisis. J. Int. Commer. Econ. Policy 2017, 8, 1-28. [CrossRef]

3. Forbes, K.; Warnock, F. Debt- and equity-led capital flow episodes. In Capital Mobility and Monetary Policy; Fuentes, M., Raddatz, C.E., Reinhart, C.M., Eds.; Central Bank of Chile: Santiago, Chile, 2014; pp. $291-322$.

4. Baek, S.; Song, C. On the determinants of surges and stops in foreign loans: An empirical investigation. Open Econ. Rev. 2016, 27, 405-445. [CrossRef]

5. Cerutti, E.; Hong, G.H. Portfolio Inflows Eclipsing Banking Inflows: Alternative Facts? (No. 18/29); Working Paper; International Monetary Fund: Washington, DC, USA, 2018.

6. Ghosh, A.R.; Kim, J.; Qureshi, M.; Zalduendo, J. Surges. J. Int. Econ. 2014, 92, 266-285. [CrossRef]

7. Montiel, P.; Reinhart, C.M. The Dynamics of Capital Movements to Emerging Economies During the 1990s. In Short-Term Capital Flows and Economic Crises; Oxford University Press: New York, NY, USA, 2001; pp. 2-28.

8. Reinhart, C.; Reinhart, V. Capital flow bonanzas: An encompassing view of the past and present. In NBER International Seminar on Macroeconomics 2008; Frankel, J., Giavazzi, Eds.; Chicago University Press: Chicago, IL, USA, 2009; pp. 9-62.

9. Forbes, K.J.; Warnock, F.E. Capital flow waves: Surges, stops, flight, and retrenchment. J. Int. Econ. 2012, 88, 235-251. [CrossRef]

10. Milesi-Ferretti, G.; Tille, C. The great retrenchment: International capital flows during the global financial crisis. Econ. Policy 2011, 26, 289-346. [CrossRef]

11. Hannan, W.A. Revisiting the Determinants of Capital Flows to Emerging Markets-A Survey of the Evolving Literature (No. 18/214); International Monetary Fund: Washington, DC, USA, 2018.

12. Koepke, R. What Drives Capital Flows to Emerging Markets; A Survey of the Empirical Literature; Institute of International Finance: Washington, DC, USA, 2015.

13. Gourio, F.; Siemer, M.; Verdelhan, A. International risk cycles. J. Int. Econ. 2013, 89, 471-484. [CrossRef]

14. Calvo, G.; Leiderman, L.; Reinhart, C.M. Inflows of capital to developing countries in the 1990s. J. Econ. Perspect. 1996, 10, 123-140. [CrossRef]

15. Chuhan, P.; Claessens, S.; Mamingi, N. Equity and bond flows to Latin America and Asia: The role of global and country factors. J. Dev. Econ. 1998, 55, 439-463. [CrossRef]

16. Fernandez-Arias, E. The new wave of private capital inflows: Push or pull? J. Dev. Econ. 1996, 48, $389-418$. [CrossRef]

17. Reyes-Heroles, R.; Tenorio, G. Regime-switching in emerging market business cycles: Interest rate volatility and sudden stops. J. Int. Money Financ. 2019, 93, 81-100. [CrossRef]

18. Taylor, M.P.; Sarno, L. Capital Flows to Developing Countries: Long- and Short-Term Determinants. World Bank Econ. Rev. 1997, 11, 451-470. [CrossRef]

19. Brunnermeier, M.K. Deciphering the Liquidity and Credit Crunch 2007-2008. J. Econ. Perspect. 2009, 23, 77-100. [CrossRef]

20. Calvo, G. Financial crises and liquidity shocks a bank-run perspective. Eur. Econ. Rev. 2012, 56, 317-326. [CrossRef]

21. Fratzscher, M.; Duca, M.L.; Straub, R. On the International Spillovers of US Quantitative Easing. Econ. J. 2017, 128, 330-377. [CrossRef]

22. Albuquerque, R.; Loayza, N.; Servén, L. World market integration through the lens of foreign direct investors. J. Int. Econ. 2005, 66, 267-295. [CrossRef]

23. Abeysinghe, T.; Forbes, K. Trade Linkages and Output-Multiplier Effects: A Structural VAR Approach with a Focus on Asia. Rev. Int. Econ. 2005, 13, 356-375. [CrossRef]

24. Forbes, K. Are trade linkages important determinants of country vulnerability to crises? In Preventing Currency Crises in Emerging Markets; Edwards, S., Frankel, J., Eds.; University of Chicago Press: Chicago, IL, USA, 2002; pp. 77-123.

25. Forbes, K.J. The Asian flu and Russian virus: The international transmission of crises in firm-level data. J. Int. Econ. 2004, 63, 59-92. [CrossRef] 
26. Glick, R.; Rose, A. Contagion and trade: Why are currency crises regional? J. Int. Money Financ. 1996, 18, 603-617. [CrossRef]

27. Kaminsky, G.; Reinhart, C.; Vegh, C. When it rains, it pours: Procyclical capital flows and macroeconomic policies. In NBER Macroeconomics Annual 2004; National Bureau of Economic Research: Cambridge, MA, USA, 2005; Volume 19, pp. 11-82.

28. Park, Y.C.; Song, C. Institutional Investors, Trade Linkage, Macroeconomic Similarities, and Contagion of the Thai Crisis. J. Jpn. Int. Econ. 2001, 15, 199-224. [CrossRef]

29. Broner, F.A.; Gelos, R.G.; Reinhart, C.M. When in peril, retrench: Testing the portfolio channel of contagion. J. Int. Econ. 2006, 69, 203-230. [CrossRef]

30. Peek, J.; Rosengren, E.S. The International Transmission of Financial Shocks: The Case of Japan. SSRN Electron. J. 1997, 87, 495-505. [CrossRef]

31. Broner, F.; Didier, T.; Erce, A.; Schmukler, S.L. Gross capital flows: Dynamics and crises. J. Monet. Econ. 2013, 60, 113-133. [CrossRef]

32. Contessi, S.; De Pace, P.; Francis, J.L. The cyclical properties of disaggregated capital flows. J. Int. Money Financ. 2013, 32, 528-555. [CrossRef]

33. Calvo, G.; Izquierdo, A.; Mejía, L.-F. Systemic Sudden Stops: The Relevance of Balance-Sheet Effects and Financial Integration; National Bureau of Economic Research: Cambridge, MA, USA, 2008.

34. Kaminsky, G. Crises and sudden stops: Evidence from international bond and syndicated-loan markets. Monet. Econ. Stud. 2008, 26, 107-130.

35. Claessens, S.; Kose, M.A. Financial Crises: Explanations, Types and Implications. SSRN Electron. J. 2013. [CrossRef]

36. Edwards, S. Thirty Years of Current Account Balances, Current Account Reversals and Sudden Stops (No. w10276); National Bureau of Economic Research: Cambridge, MA, USA, 2004.

37. Agosin, M.R.; Huaita, F. Capital flows to emerging economies: Minsky in the tropics. Camb. J. Econ. 2011, 35, 663-683. [CrossRef]

38. Fratzscher, M. Capital flows, push versus pull factors and the global financial crisis. J. Int. Econ. 2012, 88, 341-356. [CrossRef]

39. Beck, T.; Demirgüç-Kunt, A. Financial Institutions and Markets across Countries and Over Time-Data and Analysis; World Bank: Washington, DC, USA, 2009.

40. Reinhart, C.M.; Magud, N.E.; Rogoff, K.S. Capital Controls: Myth and Reality-A Portfolio Balance Approach; National Bureau of Economic Research: Cambridge, MA, USA, 2011.

41. Calvo, G.; Talvi, E. Sudden Stop, Financial Factors and Economic Collapse in Latin America. In The Washington Consensus Reconsidered: Toward a New Global Governance; Narcis, S., Stiglitz, J., Eds.; Oxford University Press: New York, NY, USA, 2008; pp. 119-149.

42. Bordo, M.; Eichengreen, B.J.; Klingebiel, D.; Martinez-Peria, M.S. Is the crisis problem more severe? Econ. Policy 2001, 16, 53-82. [CrossRef]

43. Cardarelli, R.; Elekdag, S.; Kose, A. Capital Inflows: Macroeconomic Implications and Policy Responses; Econ. Systems 2010, 34, 333-356. [CrossRef]

44. Glick, R.; Guo, X.; Hutchison, M. Currency Crises, Capital-Account Liberalization, and Selection Bias. Rev. Econ. Stat. 2006, 88, 698-714. [CrossRef]

45. Glick, R.; Hutchison, M. Capital controls and exchange rate instability in developing economies. J. Int. Money Financ. 2005, 24, 387-412. [CrossRef]

46. Ostry, J.D.; Ghosh, A.R.; Chamon, M.; Qureshi, M.S. Capital controls: When and why? IMF Econ. Rev. 2011, 59, 562-580. [CrossRef]

47. Stiglitz, J. Globalization and its Discontents; Norton: New York, NY, USA, 2002.

48. Ben Zeev, N. Capital controls as shock absorbers. J. Int. Econ. 2017, 109, 43-67. [CrossRef]

49. Forbes, K.; Fratzscher, M.; Straub, R. Capital-flow management measures: What are they good for? J. Int. Econ. 2015, 96, S76-S97. [CrossRef]

50. Fernández, A.; Klein, M.W.; Schindler, M.; Rebucci, A.; Uribe, M. Capital Control Measures: A New Dataset. IMF Econ. Rev. 2016, 64, 548-574. [CrossRef]

51. Abbas, A.; Belhocine, N.; ElGanainy, A.; Horton, M. A Historical Public Debt Database (No. 10/245); Working Paper; International Monetary Fund: Washington, DC, USA, 2010. 
52. Bătrâncea, L.; Nichita, A.; Bătrâncea, I.; Găban, L. The Strength of the relationship between shadow economy and corruption: Evidence from a worldwide country-sample. Soc. Indic. Res. 2018, 138, 1119-1143. [CrossRef]

53. Chong, A.; Calderón, C. Causality and Feedback Between Institutional Measures and Economic Growth. Econ. Polit. 2000, 12, 69-81. [CrossRef]

54. Berger, H.; Nitsch, V. The Euro's Effects on Trade Imbalances (No. 10/226); Working Paper; International Monetary Fund: Washington, DC, USA, 2010.

55. Ghosh, A.R.; Qureshi, M.S.; Tsangarides, C.G. Is the exchange rate regime really irrelevant for external adjustment? Econ. Lett. 2013, 118, 104-109. [CrossRef]

56. Magud, N.E.; Reinhart, C.M.; Vesperoni, E.R. Capital Inflows, Exchange Rate Flexibility and Credit Booms. Rev. Dev. Econ. 2014, 18, 415-430. [CrossRef]

57. Magud, N.E.; Versperoni, E.R. Exchange rate flexibility and credit during capital inflow reversals: Purgatory ... not paradise. J. Int. Money Financ. 2015, 55, 88-110. [CrossRef]

58. Ghosh, A.R.; Ostry, J.D.; Qureshi, M.S. Exchange Rate Management and Crisis Susceptibility: A Reassessment. IMF Econ. Rev. 2015, 63, 238-276. [CrossRef]

59. Chinn, M.; Wei, S.J. A faith-based initiative: Does a flexible exchange-rate regime really facilitate current account adjustment? Rev. Econ. Stat. 2013, 95, 168-184. [CrossRef]

60. Esaka, T. Are consistent pegs really more prone to currency crises? J. Int. Money Financ. 2014, 44, $136-163$. [CrossRef]

61. Mendoza, E.G.; Terrones, M.E. An Anatomy of Credit Booms: Evidence from Macro Aggregates and Micro Data; National Bureau of Economic Research: Cambridge, MA, USA, 2008.

62. Shambaugh, J.C. The Effect of Fixed Exchange Rates on Monetary Policy. Q. J. Econ. 2004, 119, 301-352. [CrossRef]

63. Alberola, E.; Erce, A.; Serena, J.M. International reserves and gross capital flows dynamics. J. Int. Money Financ. 2016, 60, 151-171. [CrossRef]

64. Bussière, M.; Cheng, G.; Chinn, M.D.; Lisack, N. For a few dollars more: Reserves and growth in times of crises. J. Int. Money Financ. 2015, 52, 127-145. [CrossRef]

65. Bartolini, L.; Drazen, A. Capital account liberalization as a signal. Am. Econ. Rev. 1997, 87, 138-154.

(C) 2019 by the authors. Licensee MDPI, Basel, Switzerland. This article is an open access article distributed under the terms and conditions of the Creative Commons Attribution (CC BY) license (http://creativecommons.org/licenses/by/4.0/). 